\title{
Zooplankton in Svalbard fjords on the Atlantic-Arctic boundary
}

\author{
Marta Gluchowska $^{1} \cdot$ Slawomir Kwasniewski $^{1} \cdot$ Agnieszka Prominska $^{1} \cdot$ \\ Anna Olszewska' ${ }^{1}$ Ilona Goszczko ${ }^{1} \cdot$ Stig Falk-Petersen $^{2,3} \cdot$ Haakon Hop $^{4}$ • \\ Jan Marcin Weslawski ${ }^{1}$
}

Received: 30 December 2015/Revised: 8 June 2016/ Accepted: 9 June 2016/Published online: 1 July 2016 (C) The Author(s) 2016. This article is published with open access at Springerlink.com

\begin{abstract}
Zooplankton abundance and community structures were studied in three west Spitsbergen fjords at the beginning of the warm phase, which seem to have entered in 2006. Sampling was conducted in summer 2007 at stations distributed along transects in Hornsund, Isfjorden and Kongsfjorden. Variations in zooplankton standing stocks and community structures (assessing taxonomic diversity and zoogeographical affiliations) were analysed in relation to the environmental variables using multivariate techniques. The hydrographic conditions in Hornsund were influenced by the cold Arctic Water, whereas those in Isfjorden and especially in Kongsfjorden were, to a greater extent, under the influence of the warm Atlantic Water. High abundances of both meroplankton and holoplankton organisms were observed in Kongsfjorden, with high contributions of boreal and ubiquitous species (Calanus finmarchicus and Oithona similis, respectively). In Hornsund at the same time, the zooplankton consisted mainly of boreo-Arctic and Arctic species, the abundances of which were comparable along the West Spitsbergen Shelf. Our
\end{abstract}

This article belongs to the special issue on the "Kongsfjorden ecosystem-new views after more than a decade of research", coordinated by Christian Wiencke and Haakon Hop.

Marta Gluchowska

mgluchowska@iopan.gda.pl

1 Institute of Oceanology Polish Academy of Sciences, Powstancow Warszawy 55, 81-712 Sopot, Poland

2 Arctic and Marine Biology, Biosciences, Fisheries and Economics, The Arctic University of Norway, 9037 Troms $\emptyset$, Norway

3 Akvaplan-niva, Fram Centre, 9296 Troms $\varnothing$, Norway

4 Norwegian Polar Institute, Fram Centre, 9296 Troms $\varnothing$, Norway results indicate that the difference in hydrography had measurable effects on the zooplankton community in the study area. Furthermore, by comparing regions of contrasting oceanographic conditions, we present evidence as to how the zooplankton structure will change in the Arctic ecosystems if the warming trends continue to operate with the same dynamics. The advection of Atlantic waters to the Arctic seas may lead to changes in zooplankton structure, with increased abundance and contributions of boreal and small ubiquitous species. The 'warmer Arctic fjords' scenarios may also induce more rapid development of both holoplankton and meroplankton populations and, consequently, modify the trophic interactions in plankton communities.

Keywords Zooplankton - Spatial distribution · West Spitsbergen fjords $\cdot$ Arctic

\section{Introduction}

Spitsbergen, the largest island in the Svalbard archipelago, is located on the border between the North Atlantic and the Arctic Ocean, and its marine ecosystems can be regarded as natural observatories for modifications resulting from changes in environmental factors, as a consequence of climatic variability. Different habitats exist in Spitsbergen ecosystems over relatively small spatial scales, and they are exposed to various external, dynamic ecosystem driving forces of regional and distant origins (Carroll et al. 2011). The West Spitsbergen Shelf (WSS) is a region where warm saline Atlantic Water (AW) of the West Spitsbergen Current (WSC), cold fresh Arctic Water (ArW) of the coastal Sørkapp Current (SC) and riverine and glacial waters are in a dynamic balance (Cottier et al. 
2010). The hydrographic conditions on the WSS are predetermined by the prevailing currents and local weather (Svendsen et al. 2002; Basedow et al. 2004), which consequently shape the fjord habitats and transmit a range of ecosystem driving forces (Saloranta and Svendsen 2001; Cottier et al. 2007, 2010).

Studies have revealed that advection of AW into the west Spitsbergen fjords, particularly Kongsfjorden, has a major impact on the pelagic system, influencing nutrient supply, bloom dynamics, species composition, population age structures, and the biomass of planktonic communities (Basedow et al. 2004; Willis et al. 2006, 2008; Walkusz et al. 2009; Rokkan Iversen and Seuthe 2011). Zooplankton production in the Spitsbergen fjords depends to a certain extent on local primary productivity (Richardson and Schoeman 2004; Trudnowska et al. 2014), but the advective transport of organisms between areas and populations also contributes to local biomass and production (Aksnes and Blindheim 1996; Heath et al. 1999; Torgersen and Huse 2005). The fjords are populated by boreal and Arctic organisms, with species from these biogeographical realms co-occurring in different proportions under different environmental conditions (Arnkværn et al. 2005; Hop et al. 2002a, b; Kwasniewski et al. 2003; Weydmann and Kwasniewski 2008; Dalpadado et al. 2015). The supply of the warm-water boreal zooplankton species to the west Spitsbergen fjords most likely supports large populations of plankton-eating fish (Stempniewicz et al. 2007; Renaud et al. 2012; Hop and Gjøsæter 2013; Nahrgang et al. 2014; Dalpadado et al. 2015), and these zooplankton exert grazing pressure on the local phytoplankton bloom (Eilertsen et al. 1989), which consequently influences the fate of the primary production and the vertical flux of organic particles (Wassmann et al. 2006; Olli et al. 2007).

During a 15-year time series of summer observations in the northern Nordic Seas and the Fram Strait region (Walczowski et al. 2012), the AW temperature and salinity showed noticeable but oscillating increases. Consequently, the plankton community is currently in transition, with arctic marine species being compromised by temperature regimes approaching the limits of their thermal capacity (Burrows et al. 2011, 2014), while a northward shift in the latitudinal distribution of boreal species has been observed (Kraft et al. 2013; Weydmann et al. 2014; Busch et al. 2015). In the Fram Strait region, a strong inflow of AW in the WSC was observed in autumn and winter 2006/2007, and temperatures have been above normal (BeszczynskaMöller et al. 2012). The present study was performed in the summer of 2007; therefore, the time at which we explored the region can be regarded as relatively warm. Fjords often carry typical features of their adjacent seas, but they retain these characteristics for longer periods than open waters; therefore, they have often been used as model ecosystems
(Buchholz et al. 2010). The large inflow of AW to Kongsfjorden during the winter of 2005/2006 (Cottier et al. 2007) switched the fjord into a warmer state with hardly any fast ice cover in the subsequent years (until 2011). Here, based on a large-scale field study, we present zooplankton community studies in three west Spitsbergen fjords at the beginning of the warmer phase, which seems to have entered the fjords on the west coast of Spitsbergen.

Most of the previous research on zooplankton has been performed in single fjords (Koszteyn and Kwasniewski 1989; Kwasniewski et al. 2003, 2013; Basedow et al. 2004; Arnkværn et al. 2005; Weydmann and Kwasniewski 2008; Walkusz et al. 2009; Trudnowska et al. 2014). However, one way to facilitate a better understanding of the influence of hydrographic characteristics on the pelagic ecosystem is to engage in comparative studies (Weslawski et al. 1991; Piwosz et al. 2009; Kwasniewski et al. 2010; Wallace et al. 2010; Rabindranath et al. 2011; Hovinen et al. 2014; Dalpadado et al. 2015). In this context, the West Spitsbergen Shelf creates a unique, natural, small-scale experimental setting because fjords occupying very close geographical locations can be influenced at the time by different water masses.

The main objective of this study was to describe the spatial variability of the zooplankton standing stock and community structure (including aspects of zooplankton ecological characteristics, such as the lifespan of the plankton, and taxonomic and zoogeographical affiliations) at three west Spitsbergen fjords reflecting a variety of oceanographic conditions from Arctic to Atlantic environments. Additionally, we identified possible connections between zooplankton distribution and hydrographic parameters that may be influenced by climate change.

\section{Materials and methods}

\section{Study area, fjord geography and summer hydrography}

The three studied fjords have different shapes and bathymetries, which influence their hydrographic conditions. Isfjorden is a large (total area $3084 \mathrm{~km}^{2}$, volume $390 \mathrm{~km}^{3}$ ) and broad fjord (Nilsen et al. 2008; Table 1). The total area of Kongsfjorden is $231 \mathrm{~km}^{2}$ (Hop et al. 2006), and the total volume is $29.4 \mathrm{~km}^{3}$ (Ito and Kudoh 1997). The area and volume of Hornsund are $320 \mathrm{~km}^{2}$ (Muckenhuber et al. 2015) and $29 \mathrm{~km}^{3}$, respectively. However, one must consider that the areas and volumes of the fjords may have changed since the publishing of the last official cartographic data because of glacial retreat (Schellenberger et al. 2015). The cross-sectional area, a characteristic that is important for estimating the theoretical time needed to 
Table 1 Main

physiogeographical features of Hornsund, Isfjorden and

Kongsfjorden

\begin{tabular}{llll}
\hline & Hornsund & Isfjorden & Kongsfjorden \\
\hline Length $(\mathrm{km})$ & 27 & 98 & 27 \\
Width $(\mathrm{km})$ & 8 & 24 & $4-10$ \\
Area $\left(\mathrm{km}^{2}\right)$ & 320 & 3084 & 231 \\
Volume $\left(\mathrm{km}^{3}\right)$ & 29 & 390 & 29 \\
Cross-sectional southern location & $76^{\circ} 54.357^{\prime} \mathrm{N}$ & $78^{\circ} 06.473^{\prime} \mathrm{N}$ & $78^{\circ} 58.981^{\prime} \mathrm{N}$ \\
$\quad$ Latitude, longitude & $15^{\circ} 23.563^{\prime} \mathrm{E}$ & $13^{\circ} 56.234^{\prime} \mathrm{E}$ & $11^{\circ} 23.281^{\prime} \mathrm{E}$ \\
Cross-sectional northern location & $76^{\circ} 59.747^{\prime} \mathrm{N}$ & $78^{\circ} 11.560^{\prime} \mathrm{N}$ & $79^{\circ} 03.019^{\prime} \mathrm{N}$ \\
$\quad$ Latitude, longitude & $15^{\circ} 14.675^{\prime} \mathrm{E}$ & $13^{\circ} 47.097^{\prime} \mathrm{E}$ & $11^{\circ} 36.459^{\prime} \mathrm{E}$ \\
Cross-sectional area $\left(\mathrm{km}^{2}\right)$ & 1.488 & 3.573 & 2.266 \\
Cross-sectional area/volume $\left(\mathrm{m}^{-1}\right)$ & 64.7 & 9.2 & 78.1 \\
\hline
\end{tabular}

exchange water masses with an adjacent shelf, was calculated based on high-resolution hydrographic sections taken on board RV 'Oceania' in summer 2008. Isfjorden, which has the largest cross-sectional area, has the lowest ratio of the cross-sectional area to the total fjord volume and, consequently, requires the most time for water exchange of the three studied fjords. The highest cross-sectional area to volume ratio is in Kongsfjorden, in which the water masses are exchanged approximately 8 times faster than in Isfjorden. Hornsund has an exchange ratio that is slightly lower than that of Kongsfjorden (Table 1).

The hydrographic conditions in the west Spitsbergen fjords are described in a number of studies (Svendsen et al. 2002; Cottier et al. 2005, 2007; Nilsen et al. 2008; Tverberg and Nøst 2009). On the shelf, cold and relatively fresh ArW originating from the Barents Sea is transported northward along the coast by the SC, whereas outside the shelf, warm and saline AW originating from the Norwegian Sea flows in the same direction in the form of the WSC (Fig. 1). These two well-defined currents are typically separated by a density-compensated front (Arctic Fronts; Swerpel 1985; Saloranta and Svendsen 2001; Cottier and Venables 2007). The lack of a distinct sill at the entrances of Kongsfjorden and Isfjorden leads to easy transfer of water from the open sea and water from the fjord (Svendsen et al. 2002; Cottier et al. 2005; Nilsen et al. 2008). The cross-shelf exchange is possible under favourable wind forcing. The initiating along-shore wind causes frontal instabilities, and the persistent northerly winds lead to upwelling of AW onto the shelf due to Ekman pumping (Cottier et al. 2005, 2007), which was shown to be strongest north and northwest of Spitsbergen (Lind and Ingvaldsen 2012). Another exchange mechanism proposed by Inall et al. (2015) involves coastaltrapped waves forming over variable slope topography and propagating onto the shelf.

During summer, the distribution of water masses in the main parts of the studied fjords typically features a twolayered structure (Cottier et al. 2010) that is composed of fresh Surface Water (SW) and saline Transformed Atlantic

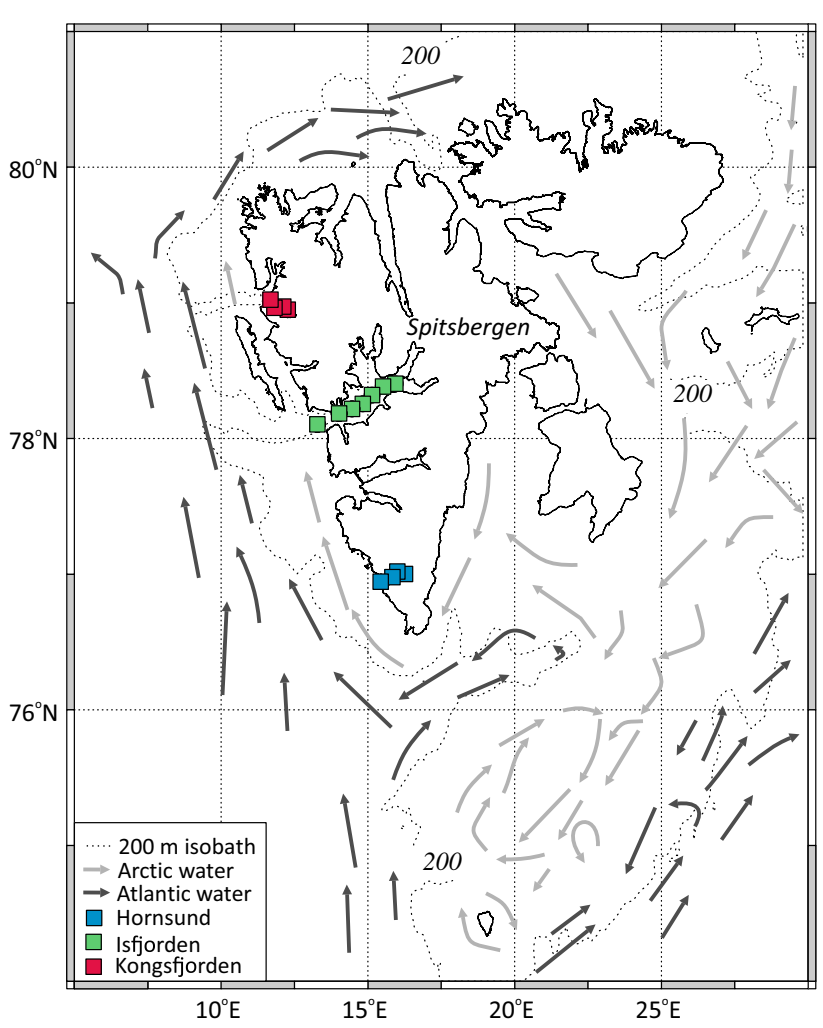

Fig. 1 Spitsbergen waters with surface current patterns (after Sakshaug et al. 2009, simplified) and locations of sampling stations

Water (TAW). However, because the innermost fjord basins are usually separated by a sill, creating semi-closed pools that, in the cases of Isfjorden and Hornsund, also have their own geographical names (Billefjorden and Brepollen, respectively), a three-layer system is often observed, due to the occurrence of water of local origin, including Local Water (LW) and Winter-Cooled Water (WCW).

\section{Zooplankton sampling and laboratory analysis}

Sampling was conducted during two cruises in the west Spitsbergen fjords, one on board RV Oceania to Hornsund 
and one on board RV Helmer Hanssen to Isfjorden and Kongsfjorden, from 22 to 27 July 2007 (Table 2).

Stratified vertical zooplankton hauls were performed with a Multi Plankton Sampler Type Midi (Hydro-Bios, Germany), consisting of five closing nets with a $0.25 \mathrm{~m}^{2}$ square opening and a $180-\mu \mathrm{m}$ mesh size. The collected samples were preserved in $4 \%$ formaldehyde solution in seawater buffered with borax. The zooplankton were sampled at different depths at the various locations. Zooplankton sampling in Hornsund was vertically stratified in a manner that reflected the hydrographic structure of the water column, as revealed by temperature and salinity measurements taken prior to the net sampling. At the remaining stations, five fixed depth strata were sampled as follows: 0-25(20)-50-100-150(200)-bottom. This sampling pattern is often used in zooplankton sampling to monitor Svalbard water masses; it generally considers the typical hydrographic stratification in the study area during summer (Walkusz et al. 2009). Typically, of the five depth layers sampled, two were in the upper water layer (down to $40-50 \mathrm{~m}$ in the inner and central basins and to $75-100 \mathrm{~m}$ in the outer basin) and three were in the lower layer, extending down to the bottom; therefore, a two-layer structure was subsequently applied to the zooplankton data processing (upper and lower layers; Table 2). Hydrographic data were obtained from all zooplankton stations. Continuous profiles, from the surface to the bottom, of temperature and salinity were measured using the Sea-Bird
Electronics, Inc. CTD (SBE 911plus) system (composed of duplicate SBE 3plus temperature sensors, SBE 4C conductivity sensors and a Digiquartz ${ }^{\circledR}$ pressure sensor, all calibrated by the manufacturer before the cruise), and the raw data were then subjected to conventional processing.

In the laboratory, each zooplankton sample was first scanned for macrozooplankton (organisms with a total length $>5 \mathrm{~mm}$ ), which were selected, identified and counted in the entire sample. The remaining mesozooplankton size fraction was examined for taxonomic composition and abundance using a subsampling method (Postel et al. 2000). Two-millilitre subsamples was taken using a macropipette (an equivalent of the Stempel pipette), and all organisms in each subsample were identified and enumerated. The number of subsamples varied to allow the counting of at least 500 individuals per sample (Postel et al. 2000). Calanus was identified to the species level at each developmental stage based on the description by Kwasniewski et al. (2003, 2012). Other zooplankters were identified to the lowest possible taxonomic level.

\section{Data analysis}

\section{Hydrography}

CTD data sets from both cruises were processed using SBE Data Processing Software. The profiles were vertically averaged with 1-m intervals. Further calculations and

Table 2 Metadata of zooplankton sampling in the studied fjords of west Spitsbergen in summer 2007

\begin{tabular}{|c|c|c|c|c|c|c|}
\hline \multirow[t]{2}{*}{ Station } & \multirow[t]{2}{*}{ Latitude $\left({ }^{\circ} \mathrm{N}\right)$} & \multirow[t]{2}{*}{ Longitude $\left({ }^{\circ} \mathrm{E}\right)$} & \multirow[t]{2}{*}{ Date 2007} & \multirow[t]{2}{*}{ Bottom depth (m) } & \multicolumn{2}{|c|}{ Layer extent (m) } \\
\hline & & & & & Upper & Lower \\
\hline \multicolumn{7}{|c|}{ Hornsund } \\
\hline $\mathrm{H} 3$ & 77.01 & 16.48 & 27.07 & 125 & $40-20-0$ & $115-70-40$ \\
\hline $\mathrm{H} 2$ & 76.99 & 15.91 & 27.07 & 140 & $50-20-0$ & $130-100-50$ \\
\hline $\mathrm{H} 4$ & 76.98 & 15.74 & 27.07 & 240 & $50-10-0$ & $230-90-50$ \\
\hline H1 & 76.92 & 15.26 & 27.07 & 180 & $75-50-10-0$ & $170-75$ \\
\hline \multicolumn{7}{|c|}{ Isfjorden } \\
\hline $\mathrm{D} 2 \mathrm{~b}$ & 78.38 & 15.82 & 23.07 & 181 & $50-25-0$ & $170-150-100-50$ \\
\hline D3 & 78.34 & 15.58 & 22.07 & 192 & $50-25-0$ & $170-150-100-50$ \\
\hline KE9 & 78.28 & 15.21 & 23.07 & 224 & $50-25-0$ & $210-150-100-50$ \\
\hline KE8 & 78.24 & 15.08 & 23.07 & 221 & $50-25-0$ & $210-150-100-50$ \\
\hline $\mathrm{D} 4 \mathrm{~b}$ & 78.16 & 14.39 & 24.07 & 241 & $50-25-0$ & $200-150-100-50$ \\
\hline D5 & 78.03 & 13.95 & 24.07 & 304 & $100-50-25-0$ & $270-150-100$ \\
\hline D7 & 78.07 & 13.18 & 24.07 & 304 & $100-50-25-0$ & $270-150-100$ \\
\hline \multicolumn{7}{|c|}{ Kongsfjorden } \\
\hline $\mathrm{Kb} 3$ & 78.95 & 11.96 & 26.07 & 340 & $50-20-0$ & $300-200-100-50$ \\
\hline $\mathrm{Kb} 2$ & 78.98 & 11.74 & 26.07 & 240 & $50-20-0$ & $220-200-100-50$ \\
\hline $\mathrm{Kb} 1$ & 79.01 & 11.43 & 26.07 & 342 & $50-20-0$ & $300-200-100-50$ \\
\hline $\mathrm{Kb} 0$ & 79.04 & 11.14 & 27.07 & 322 & $50-20-0$ & $310-200-100-50$ \\
\hline
\end{tabular}


visualisation were performed in the MathWorks MATLAB environment. In addition to the data from all zooplankton stations, data collected in the inner part of Isfjorden (Billefjorden), Hornsund (Brepollen) and inner Kongsfjorden (IOPAS data) were considered when plotting the $\theta-$ $S$ diagram and revealing each basin's hydrography.

Water mass domains were defined based on the potential temperature $(\theta)$ and salinity ranges given in Nilsen et al. (2008). The most fresh and warm domain is SW, which is a product of the summer melting of glaciers, sea ice and snow, and may form in the sea or be a result of the mixing of seawater and melt water transported by glaciers and terrestrial river run-off. This water mass also partially originates from the Barents Sea with the SC. On the shelf, the AW mixes with ArW carried by the SC, and as a result, TAW is produced. Inside the fjords, three locally formed water masses are identified: Intermediate Water (IW), LW and WCW. WCW is a product of winter cooling and brine release during ice formation, and it results in increased water density. To support the statistical analysis of zooplankton data, the mean water temperature and salinity were calculated for the extent of each zooplankton layer.

\section{Zooplankton}

Various characteristics of the zooplankton community structure and standing stock (total zooplankton abundance) were used to compare the zooplankton from different fjords. The zooplankton community structure was determined based on the relative abundance of zooplankton species or taxa. All zooplankton taxa were also classified according to their lifespan as plankton (holoplankton, meroplankton; Raymont 1980). To investigate the zoogeographical aspect of community structure, all holoplankton taxa identified to the species level were divided into four categories according to their centres of distribution (regarded as ubiquitous, Arctic, boreal and boreoArctic; Corkett and McLaren 1979; Conover 1988; Unstad and Tande 1991; Park 1994; Koszteyn et al. 1995; Dalpadado and Skjoldal 1996; Dalpadado et al. 2001; Beuchel and Lønne 2002; Kosobokova et al. 2002, 2011; Head et al. 2003; Razouls et al. 2005-2015; Willis et al. 2006; Hirche and Kosobokova 2007; Graeve et al. 2008; Ji et al. 2012 as well as WoRMS - the World Register of Marine Species; WoRMS Editorial Board 2015).

Both univariate and multivariate nonparametric permutational ANOVAs (PERMANOVA; Anderson 2001; Anderson et al. 2008) were performed to test the differences in hydrography, zooplankton community structure and standing stock among the different areas. The hydrographic characteristics and zooplankton data from the different fjord habitats were analysed using a three-factor fixed model design with the following factors: fjord (fixed), station (to account for replicate variability, random and nested in the fjord) and water layer (fixed). The calculation of the Pseudo- $F$ and $p$ values was based on 999 permutations of the residuals under a reduced model.

The univariate descriptors included water temperature and salinity, total zooplankton abundance, and the abundances of meroplankton, holoplankton, ubiquitous holoplankton, Arctic holoplankton, boreal holoplankton and boreo-Arctic holoplankton. All univariate tests were conducted using PERMANOVA on Euclidean distance similarity matrices. For the multivariate analysis of the zooplankton community structure (according to lifespan as plankton, taxonomic and zoogeographical affiliations), Bray-Curtis similarity was used to calculate the resemblance matrix on relative abundance data. Prior to the analysis data were square-root-transformed to ensure a more balanced view of the assemblage structure by reducing the influence of the most numerous taxa (Clarke and Gorley 2001). The patterns of zooplankton community structures were illustrated with PCO ordinations. Spearman's rank correlation vectors of taxonomic and zoogeographical composition with two canonical axes were overlaid on the PCO plots.

A distance-based linear model (DistLM) was used to analyse and model the relationships between the zooplankton assemblages (defined according to lifespan as plankton, taxonomic and zoogeographical affiliations) and the hydrographic characteristics. Relative zooplankton abundances were square-root-transformed before the analysis. In all models, a forward-selection procedure was used to determine the best combination of predictor variables for explaining the variations in zooplankton assemblages. The selection criteria chosen for the best-fitting relationship were based on $R^{2}$ values (Anderson et al. 2008). Complementary to these analyses, nonparametric Spearman's rankorder correlations were computed between selected univariate zooplankton characteristics (total zooplankton abundance, abundances of meroplankton and holoplankton and abundances of the four zoogeographical holoplankton categories) and hydrographic parameters.

All described statistical analyses were performed using PRIMER 6 and PERMANOVA+ (Clarke and Warwick 2001; Anderson et al. 2008) as well as STATISTICA 10 (StatSoft, Inc.). The significance level for all statistical tests used was $p=0.05$.

\section{Results}

In the 69 collected samples, a total of 68 taxa representing 10 phyla were identified (including 51 species/genera and 17 taxa identified to a rank higher than genus). The phyla, ranked in order of decreasing relative contribution to the 
total zooplankton abundance, were as follows: Arthropoda (primarily Maxillopoda), Mollusca (Bivalvia and Gastropoda), Echinodermata, Chordata (Larvacea), Chaetognatha, Annelida (Polychaeta), Ctenophora, Cnidaria (Hydrozoa), Bryozoa and Nemertea.

The zooplankton in Hornsund were sampled at stations with bottom depths varying between 125 and $240 \mathrm{~m}$ (Table 2). The seawater temperature in the fjord ranged between $-1.17{ }^{\circ} \mathrm{C}$ and $4.16{ }^{\circ} \mathrm{C}$, and the salinity ranged between 32.23 and 34.77 (Fig. 2). There was no AW, but TAW was observed at the outermost station below a depth of $115 \mathrm{~m}$. The main fjord basin was primarily occupied by IW and SW. Two other water masses (LC and WCW) were also found in Hornsund, but their distribution was limited to the innermost part of the fjord (Brepollen), which is separated by a sill at a depth of $50 \mathrm{~m}$.

The total abundances of zooplankton at stations in

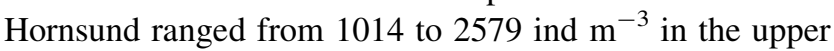
layer and from 523 and 942 ind m $^{-3}$ in the lower layer (Fig. 3a). Holoplankton composed $>93 \%$ of the total zooplankton abundance (Fig. 4b) and were predominately represented by boreo-Arctic species $(17-76 \%$ of all holoplankton organisms, Fig. 4c). The predominant zooplankton components were copepods, represented by
Oithona similis, two Calanus species (C. finmarchicus and C. glacialis) and Pseudocalanus spp. (Table 4; Fig. 4a), which together constituted $>50 \%$ of the zooplankton in the fjord. Notably, the zooplankton community in Hornsund also exhibited a universal presence of Acartia longiremis and a small proportion of meroplankton $(<7 \%$ of the total zooplankton abundance, mainly represented by Bivalvia veliger).

Zooplankton samples from Isfjorden were taken at locations with bottom depths between 181 and $304 \mathrm{~m}$ (Table 2). The seawater temperature in the fjord ranged between $-0.29{ }^{\circ} \mathrm{C}$ and $7.46{ }^{\circ} \mathrm{C}$, and salinity ranged between 32.41 and 35.05. Five distinct water masses were observed there (Fig. 2). The presence of TAW was well recognised in the fjord, and there was also a small amount of AW $\left(\theta>3{ }^{\circ} \mathrm{C}\right.$ and $\left.S>34.9\right)$ at the entrance. The main fjord basin was occupied mainly by LW (below $80 \mathrm{~m}$ ), with a layer of IW above and SW in the upper $20 \mathrm{~m}$.

The total zooplankton abundance in Isfjorden amounted

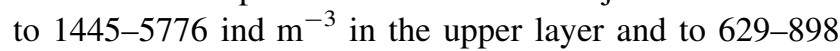
ind $\mathrm{m}^{-3}$ in the lower layer (Fig. 3a). Holoplankton composed $46-82 \%$ of zooplankton in the upper layer and $>80 \%$ in the lower layer (Fig. 4b). Holoplankton were mainly represented by the ubiquitous $O$. similis (both (a)

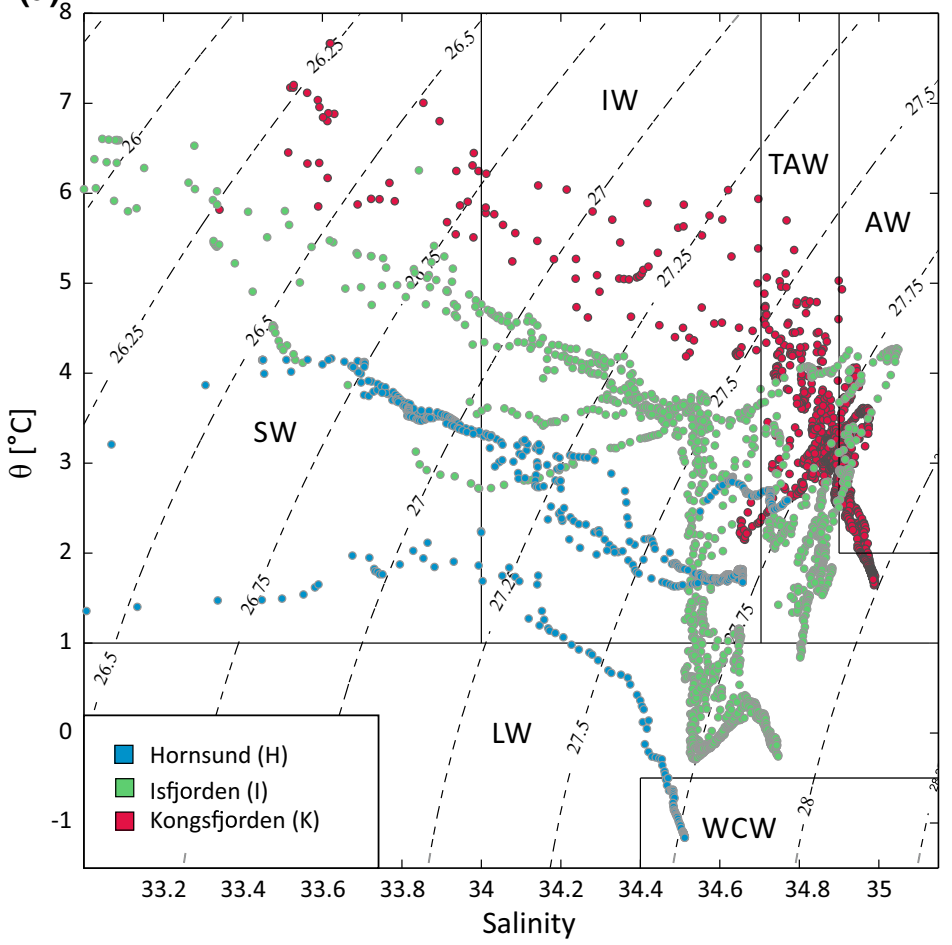

(b)
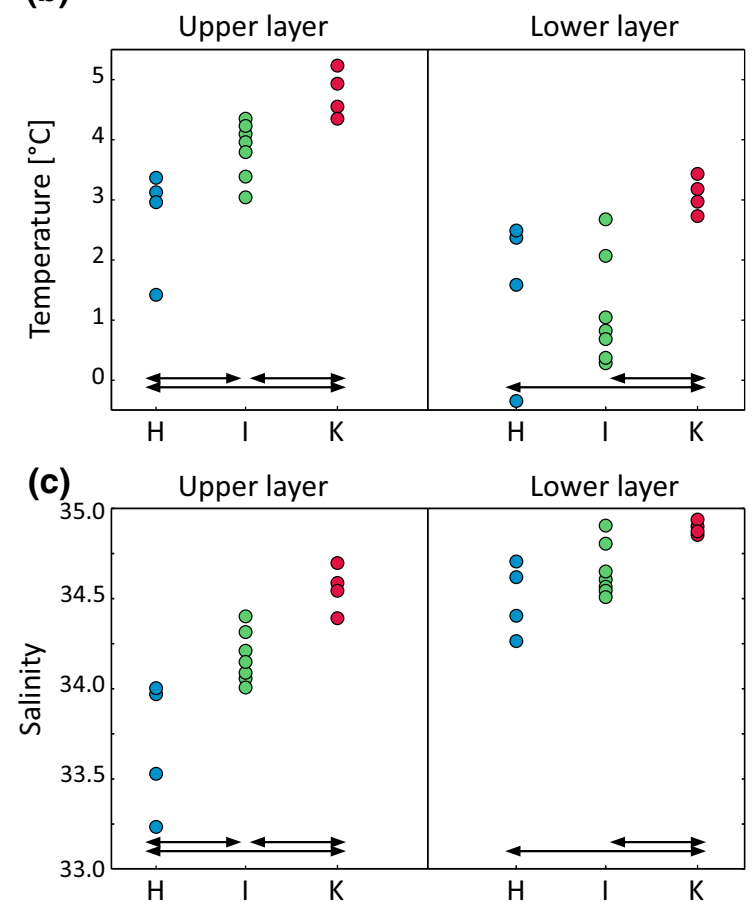

Fig. 2 Temperature and salinity diagram (a) as well as the mean temperature (b) and salinity (c) of the sampled water layers, for measurements taken at the sampling stations in summer 2007. The data are superimposed on the water mass domains described in the 'Materials and Methods': Atlantic Water (AW), Transformed Atlantic
Water (TAW), Intermediate Water (IW), Local Water (LW), Surface Water (SW) and Winter-Cooled Water (WCW). The results of pairwise post hoc PERMANOVA tests between fjords are presented for each layer, with significant differences $(p<0.05)$ marked by arrows 
(a) Total zooplankton

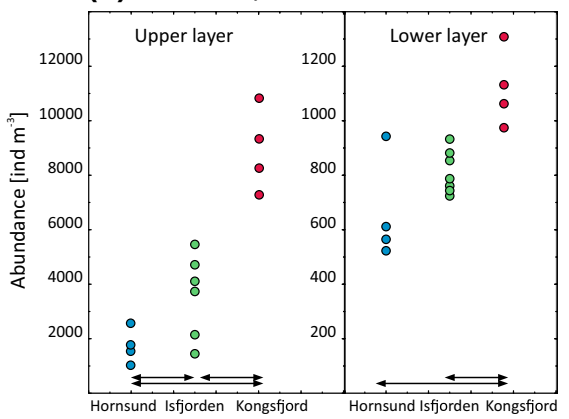

(b) Holoplankton

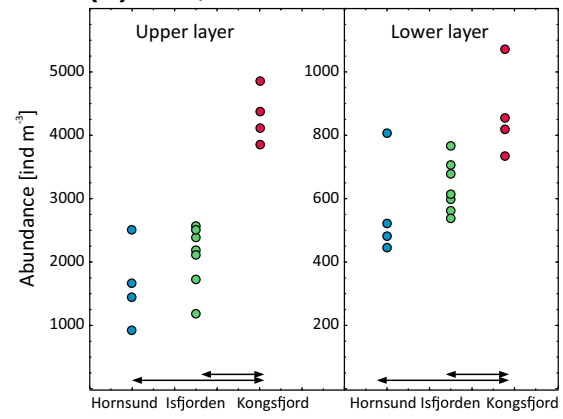

(c) Meroplankton

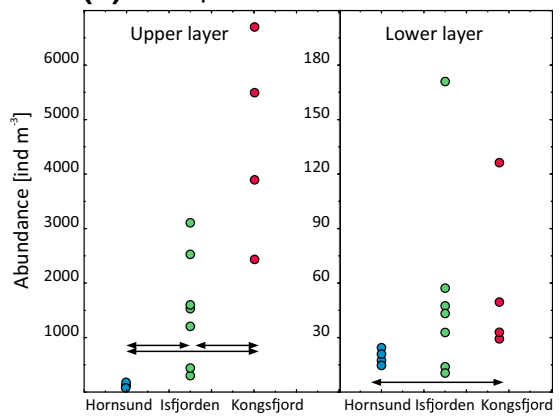

Fig. 3 Comparison of zooplankton abundances (total, holoplankton and meroplankton) in the west Spitsbergen fjords (upper and lower layers). The results of pairwise post hoc PERMANOVA tests between

fjords are presented for each layer, with significant differences $(p<0.05)$ marked by arrows

(a) Relative composition - taxonomy
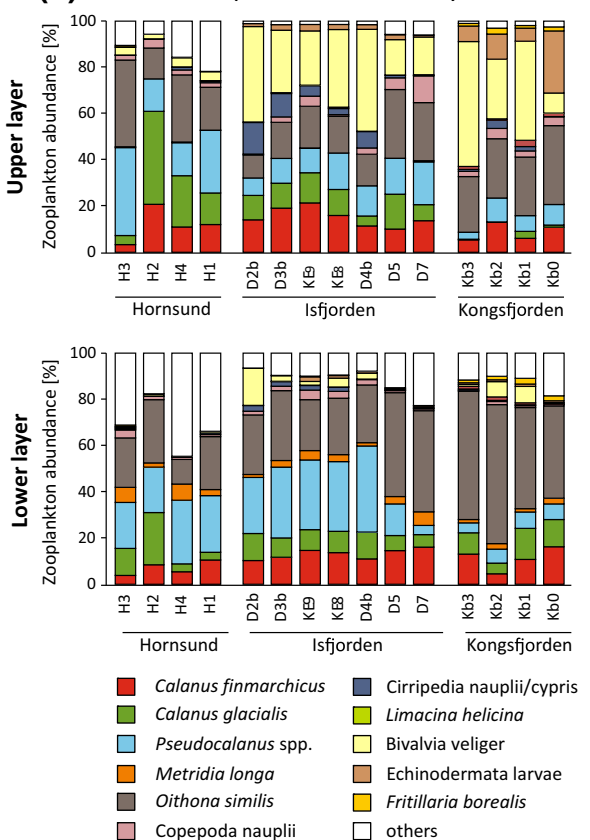

(b) Relative composition - life-span as plankton
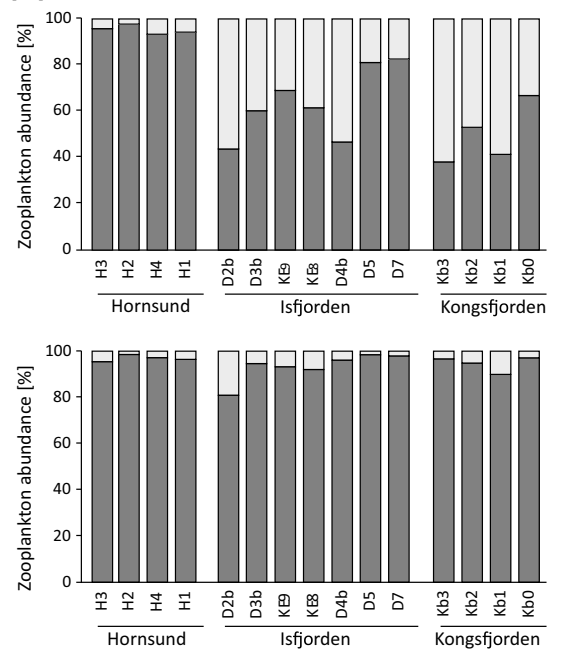

$\square$ Holoplankton

$\square$ Meroplankton (c) Relative composition - zoogeography
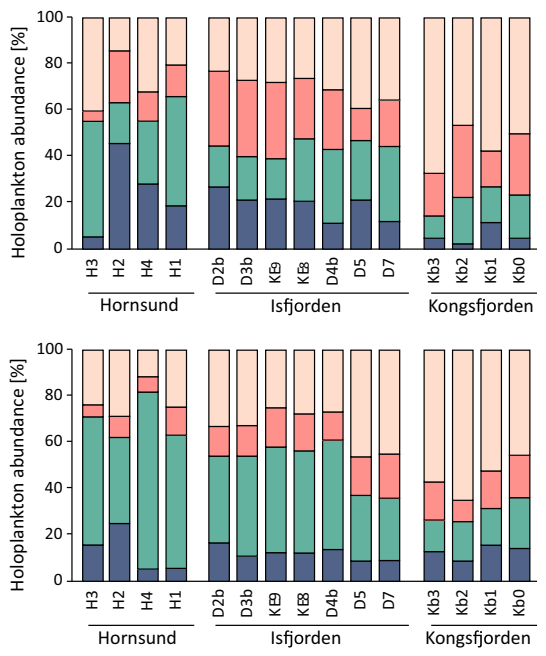

$\square$ Arctic

$\square$ Boreo-Arctic

$\square$ Boreal

$\square$ Ubiquitous

Fig. 4 Relative zooplankton abundance according to the taxonomic composition (a), lifetime spent as plankton (b) and zoogeographical holoplankton composition (c) in the west Spitsbergen fjords for the upper and lower layers

layers) and boreo-Arctic Pseudocalanus species (lower layer, Fig. 4c), whereas meroplankton was dominated by Bivalvia veligers (Fig. 4a).

Zooplankton in Kongsfjorden were sampled at stations with water depths ranging between 240 and $342 \mathrm{~m}$ (Table 2). The fjord was dominated by warm and saline water of Atlantic origin (Fig. 2). The temperature ranged from 1.64 to $7.66{ }^{\circ} \mathrm{C}$, and the salinity ranged from 33.34 to 34.99. Below the thin (approximately $10 \mathrm{~m}$ ) layer of SW, the IW was present reaching a depth of $30 \mathrm{~m}$. Large parts of the fjord were occupied by TAW, but AW was only observed at the outermost station below $130 \mathrm{~m}$. LW was not observed in the fjord during the study period.
The total abundances of zooplankton in Kongsfjorden exceeded those from the other fjords and ranged from 7280 to 10,829 ind $\mathrm{m}^{-3}$ in the upper layer and from 861 to 1249 ind $\mathrm{m}^{-3}$ in the lower layer (Fig. 3a). In the upper layer, high abundances of both meroplankton and holoplankton organisms were observed (Fig. 4b). Holoplankton was dominated by the ubiquitous $O$. similis $(46-67 \%$ of all holoplankton abundance), whereas the main meroplankton components were Bivalvia veligers and Echinodermata larvae (Fig. 4a). In the lower layer, the holoplankton organisms dominated (90-97\% of the total zooplankton abundance), with $O$. similis, C. finmarchicus and C. glacialis as the most numerous species (Fig. $4 \mathrm{a}, \mathrm{b}$ ). 


\section{Interregional comparison of the west Spitsbergen fjords}

The seawater temperature and salinity differed between the water layers (Estimated Components of Variance, ECV\% in Table 3), but differences were also observed between the fjords. The lowest temperature and salinity in the upper water layer were recorded in Hornsund, and the highest observed values were in Kongsfjorden (Fig. 2b, c). In the lower water layer, the temperature was low in Hornsund and Isfjorden but higher in Kongsfjorden. The salinity showed a similar increasing trend, being lowest in Hornsund and highest in Kongsfjorden, with intermediate values in Isfjorden (Fig. 2b, c).

The highest variability in total zooplankton abundance was associated with different water layers in the fjords (Table 3). The highest concentration of zooplankton was found above $50 \mathrm{~m}$, where the abundances were approximately 10 times higher than those in the lower layers (Table 4). Meanwhile, the total zooplankton abundance differed significantly between the fjords (Table 3). In general, the average zooplankton abundance was higher in Kongsfjorden than in the other fjords, for both meroplankton and holoplankton (Fig. 3). The total zooplankton abundance in Hornsund and Isfjorden differed only in the upper water layer, mainly due to the higher meroplankton abundance in Isfjorden (Fig. 3a, c). There were also significant differences (PERMANOVA, Table 5) between the fjords in terms of the contributions of holoplankton and meroplankton. Their abundances were highest in the upper water layer, where meroplankton composed 4-7, 17-56 and 47-62 \% of the zooplankton in Hornsund, Isfjorden and Kongsfjorden, respectively (Fig. 4b).

The results of the PERMANOVA indicate that the zooplankton community differed both among the fjords and among the water layers, but there were no significant differences among stations within a single fjord (Table 5). The differences in community structure (taxonomic and zoogeographical composition) among the fjords had a stepwise character, but the magnitude of the difference varied for the different depth layers (Table 5). The scale of the two effects mentioned above is illustrated on the PCO plots (Fig. 5). Generally, the community taxonomic structure was much more similar in the lower layers, than in the upper layers, as indicated by the overall spread of distances between the points on the diagram representing samples from the individual layers from separate fjords. Calanus glacialis, Parasagitta elegans and Mertensia ovum occurred in higher proportions in Hornsund than in the other fjords (Fig. 5a), even though their absolute concentrations in the water column were comparable (Table 4). The relative and absolute abundances of $O$. similis, Fritillaria borealis, C. finmarchicus and meroplankton taxa (Bivalvia veligers, Echinodermata larvae, Cirripedia nauplii/cypris), on the other hand, were higher in Kongsfjorden than in Isfjorden and were markedly higher than in Hornsund (Table 4; Fig. 5). The differences among the fjords in the lower layer were less pronounced but generally followed the pattern observed for the surface layer.

The absolute abundances of boreal and ubiquitous holoplankton differed significantly among the fjords, but the abundances of Arctic and boreo-Arctic holoplankton did not differ (Table 4). The fjords also differed in terms of the relative abundances of the zoogeographical categories (Table 5; Fig. 5b). The variability of the holoplankton structure in terms of zoogeographical affiliation of species was more pronounced for the differences between the fjords than for the differences between water layers (ECV\%; Table 5). The holoplankton in Hornsund were represented mainly by boreo-Arctic and Arctic species, whereas in Kongsfjorden, they primarily consisted of ubiquitous and boreal species (Figs. 4c, 5b).

\section{Zooplankton distribution pattern versus hydrography}

The DistLM analyses suggested a possibility of significant effects of both hydrographic characteristics (temperature and salinity) on shaping the zooplankton community structure in terms of the taxonomic and zoogeographical composition (Table 6). The greatest effect on the observed variations $(25-30 \%)$ was caused by the difference in water temperature. In the upper water layer, the total zooplankton abundance, as well as the abundances of the groups distinguished according to planktonic lifespan and zoogeographical affiliations, correlated positively with salinity and temperature (Spearman's rank-order correlation; Table 7), with the exception of holoplankton with Arctic or boreoArctic affiliations; their roles did not vary among the zooplankton communities from different fjords, despite different salinities. In the lower layer, the abundance of holoplankton species with boreo-Arctic affiliation was higher in cold water and water with lower salinity, whereas the abundance of ubiquitous species was higher in warm and saline waters, reflecting Arctic and Atlantic conditions, respectively.

\section{Discussion}

The west-facing Spitsbergen fjords are adjacent to the West Spitsbergen Current and thus experience a much greater influence of warm and saline Atlantic Water than do other Arctic fjords (Saloranta and Svendsen 2001; Cottier et al. 2005, 2010). The results of the hydrographic measurements suggest that during the time when this zooplankton study 


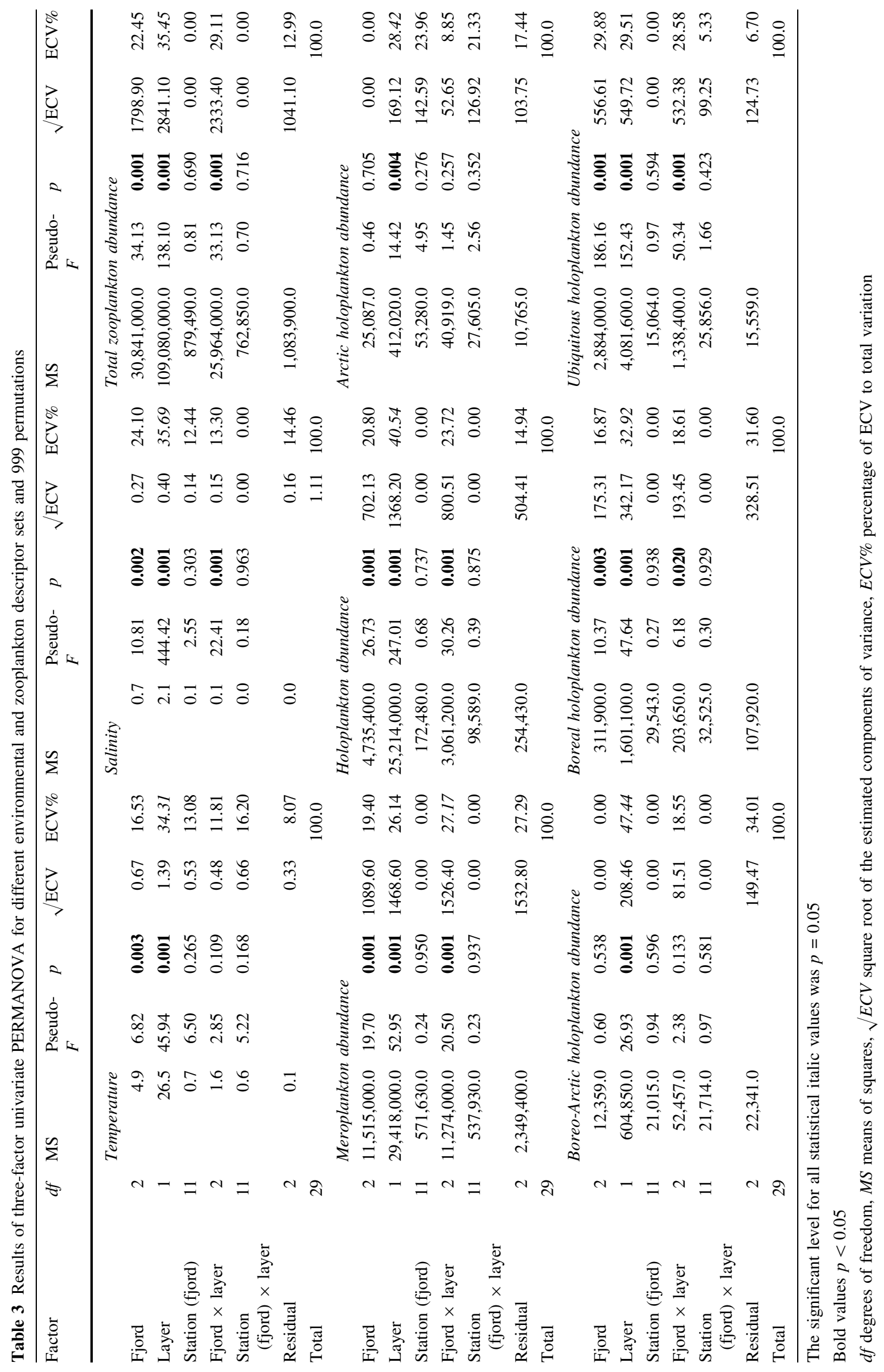


Table 4 Zooplankton abundance (ind $\mathrm{m}^{-3}$ ) in the upper and lower layers in Hornsund, Isfjorden and Kongsfjorden for different plankton lifetimes, zoogeographical affiliations and most abundant zooplankton species groups

\begin{tabular}{|c|c|c|c|c|c|c|c|c|}
\hline \multirow{2}{*}{$\begin{array}{l}\text { Zooplankton } \\
\text { classification }\end{array}$} & \multirow{2}{*}{$\begin{array}{l}\text { Zoogeographical } \\
\text { affiliations }\end{array}$} & \multirow[t]{2}{*}{ Dominants } & \multicolumn{3}{|l|}{ Upper layer } & \multicolumn{3}{|c|}{ Lower layer } \\
\hline & & & Hornsund & Isfjorden & Kongsfjorden & Hornsund & Isfjorden & Kongsfjorden \\
\hline \multirow[t]{19}{*}{ Holoplankton } & & & $947-2521$ & $1194-2585$ & $3868-4865$ & 499-927 & $616-796$ & $831-1122$ \\
\hline & Arctic & & $86-1100$ & $122-636$ & $91-418$ & $30-227$ & $55-118$ & $78-173$ \\
\hline & & C. glacialis & $69-1037$ & $100-578$ & $3-204$ & $19-213$ & $34-105$ & $41-136$ \\
\hline & & C. hyperboreus & $0-3$ & $0-8$ & $2-7$ & $3-5$ & $2-15$ & $7-25$ \\
\hline & & $\begin{array}{r}\text { Limacina } \\
\text { helicina }\end{array}$ & $1-4$ & $2-25$ & 58-203 & $0-2$ & $0-1$ & $5-22$ \\
\hline & & $\begin{array}{l}\text { Parasagitta } \\
\text { elegans }\end{array}$ & $9-50$ & $13-38$ & $8-20$ & $3-9$ & $3-6$ & $4-6$ \\
\hline & Boreo-Arctic & & $252-823$ & $332-674$ & $374-861$ & $265-446$ & $165-368$ & $113-209$ \\
\hline & & $\begin{array}{l}\text { Pseudocalanus } \\
\text { spp. }\end{array}$ & $144-668$ & $268-646$ & $332-759$ & $104-185$ & $25-308$ & $37-85$ \\
\hline & & $\begin{array}{l}\text { Microcalanus } \\
\text { spp. }\end{array}$ & $0-44$ & $0-26$ & $0-12$ & $9-77$ & $12-65$ & $29-56$ \\
\hline & & Triconia borealis & $2-7$ & $0-10$ & $12-47$ & $5-31$ & $5-27$ & $11-46$ \\
\hline & & Metridia longa & $0-6$ & $0-7$ & $0-2$ & $15-43$ & $11-37$ & $13-26$ \\
\hline & & Oikopleura spp. & $0-2$ & $2-8$ & $2-36$ & $0-4$ & $2-5$ & $1-5$ \\
\hline & & $\begin{array}{c}\text { Eukrohnia } \\
\text { hamata }\end{array}$ & $0-46$ & $0-1$ & $0-4$ & $2-10$ & $0-6$ & $3-7$ \\
\hline & Boreal & & $74-541$ & $206-799$ & $566-1282$ & $25-83$ & $91-117$ & $82-179$ \\
\hline & & C. finmarchicus & $58-535$ & $197-799$ & $406-1076$ & $20-79$ & $91-102$ & $46-141$ \\
\hline & & $\begin{array}{r}\text { Fritillaria } \\
\text { borealis }\end{array}$ & $0-10$ & $0-2$ & $115-158$ & $0-3$ & $0-2$ & $10-34$ \\
\hline & & $\begin{array}{l}\text { Oithona } \\
\text { atlantica }\end{array}$ & $6-8$ & $0-10$ & $6-52$ & $2-4$ & $0-15$ & $8-18$ \\
\hline & Ubiquitous & & $290-663$ & $364-676$ & $1914-2607$ & $67-260$ & $155-296$ & $433-578$ \\
\hline & & Oithona similis & $288-659$ & $363-676$ & 1914-2606 & $65-258$ & $154-296$ & $430-577$ \\
\hline \multirow[t]{4}{*}{ Meroplankton } & & & $58-89$ & $251-3082$ & $2415-6699$ & $14-24$ & $10-171$ & $29-126$ \\
\hline & & Bivalvia veliger & $40-60$ & $235-2258$ & $891-5851$ & $2-8$ & $2-144$ & $3-93$ \\
\hline & & $\begin{array}{l}\text { Echinodermata } \\
\text { larvae }\end{array}$ & $0-4$ & $11-106$ & $388-1504$ & $0-2$ & $1-14$ & $4-14$ \\
\hline & & $\begin{array}{l}\text { Cirripedia } \\
\text { nauplii/cypris }\end{array}$ & $0-12$ & $2-749$ & $11-365$ & $0-4$ & $1-22$ & $5-7$ \\
\hline Total abundance & & & $1014-2579$ & $1445-5476$ & $7280-10,829$ & $523-942$ & $629-898$ & $861-1249$ \\
\hline
\end{tabular}

was performed, the fjord that was most affected by the AW was Kongsfjorden, whereas Hornsund was filled with waters transported by the coastal SC. Atlantic Water has been observed in Kongsfjorden and Isfjorden on several occasions due to the reduced effectiveness of the density front at the fjord mouth (Cottier et al. 2005; Nilsen et al. 2008, 2016). Differences in bottom topography (a shallow and narrow depression near Hornsund versus broad and deep troughs leading to Isfjorden and Kongsfjorden) may be the reason why AW was only observed on the shelf and close to the mouth of Hornsund in some years. In summer 2014, AW was observed for the first time in the main Hornsund basin (Prominska et al. in review), which may indicate a regime shift in the Arctic ecosystem. The present study was performed in summer 2007, at the beginning of a relatively warm period but still at a time when Hornsund could be regarded as an Arctic, cold fjord. A comparison between fjordic ecosystems at similar latitudes, but with differences in the amounts of Atlantic and Arctic waters, is a useful approach that can allow us to better understand changes in zooplankton community structure depending on the magnitude of advection of primarily AW (Svendsen et al. 2002). Comparisons of regions with contrasting hydrographic conditions have indicated that the increasing influx of Atlantic water to the Arctic seas is likely to affect the abundance and behaviour of individual zooplankton 
Table 5 Results of three-factor multivariate PERMANOVA for the zooplankton community structure according to the taxonomic composition, lifetime spent as plankton and zoogeographical holoplankton composition (999 permutations)

\begin{tabular}{|c|c|c|c|c|c|c|}
\hline Factor & $d f$ & MS & Pseudo- $F$ & $p$ & $\sqrt{\mathrm{ECV}}$ & $\mathrm{ECV} \%$ \\
\hline \multicolumn{7}{|c|}{ Zooplankton-taxonomic composition } \\
\hline Fjord & 2 & 3208.7 & 8.50 & 0.001 & 17.50 & 22.2 \\
\hline Layer & 1 & 6108.7 & 21.67 & 0.001 & 20.85 & 26.4 \\
\hline Station (fjord) & 11 & 367.6 & 1.62 & 0.184 & 8.22 & 10.3 \\
\hline Fjord $\times$ layer & 2 & 803.9 & 2.89 & 0.005 & 10.70 & 13.6 \\
\hline Station $($ fjord) $\times$ layer & 11 & 272.5 & 1.20 & 0.350 & 6.64 & 8.4 \\
\hline Residual & 2 & 226.4 & & & 15.05 & 19.1 \\
\hline Total & 29 & & & & & 100.0 \\
\hline \multicolumn{7}{|c|}{ Zooplankton-planktonic lifespan } \\
\hline Fjord & 2 & 598.1 & 11.65 & 0.004 & 7.69 & 21.0 \\
\hline Layer & 1 & 2081.1 & 178.92 & 0.001 & 12.42 & 33.9 \\
\hline Station (fjord) & 11 & 50.0 & 0.88 & 0.584 & 0.00 & 0.0 \\
\hline Fjord $\times$ layer & 2 & 388.3 & 33.72 & 0.001 & 9.04 & 24.6 \\
\hline Station $($ fjord) $\times$ layer & 11 & 11.2 & 0.20 & 0.778 & 0.00 & 0.0 \\
\hline Residual & 2 & 56.6 & & & 7.53 & 20.5 \\
\hline Total & 29 & & & & & 100.0 \\
\hline \multicolumn{7}{|c|}{ Holoplankton-zoogeographical composition } \\
\hline Fjord & 2 & 767.5 & 11.33 & 0.001 & 8.70 & 28.9 \\
\hline Layer & 1 & 377.4 & 6.01 & 0.010 & 4.85 & 16.1 \\
\hline Station (fjord) & 11 & 65.9 & 2.70 & 0.208 & 4.45 & 14.8 \\
\hline Fjord $\times$ layer & 2 & 69.5 & 1.12 & 0.402 & 1.29 & 4.3 \\
\hline Station $($ fjord) $\times$ layer & 11 & 60.8 & 2.49 & 0.159 & 5.89 & 19.6 \\
\hline Residual & 2 & 24.4 & & & 4.94 & 16.4 \\
\hline Total & 29 & & & & & 100.0 \\
\hline
\end{tabular}

The significant level for all statistical italic values was $p=0.05$

Bold values $p<0.05$

$d f$ degrees of freedom, $M S$ means of squares, $\sqrt{ } E C V$ square root of the estimated components of variance, $E C V \%$ percentage of ECV to total variation species (e.g. diel vertical migration; Wallace et al. 2010; Rabindranath et al. 2011; Berge et al. 2014) and will lead to changes in the growth and life history characteristics of polar cod (Nahrgang et al. 2014), may have a negative impact on Little Auks' energy budget (Kwasniewski et al. 2010; Jakubas et al. 2011), and may even alter the concentration and bioaccumulation of persistent organic pollutants in zooplankton (Hallanger et al. 2011), with consequences for magnification in marine food chains (Hop et al. 2002a, b).

This study indicates that the difference in total zooplankton abundance in the west Spitsbergen fjords was most evident in the upper layers and was primarily associated with meroplankton occurrence. Meroplankton were mainly concentrated in the upper layer, probably because of the better feeding conditions in the euphotic zone. The maximum abundance of meroplankton in the upper $50 \mathrm{~m}$ was 6700 ind $\mathrm{m}^{-3}$ in Kongsfjorden $(62 \%$ of the total zooplankton abundance), and the minimum was 58 ind $\mathrm{m}^{-3}$ in Hornsund; the main meroplankton components were larvae of Bivalvia, Echinodermata and Cirripedia.
Meroplankton diversity and abundance have defined seasonal pulses of occurrence, with rich and abundant assemblages developing during the highly productive seasons (Kuklinski et al. 2013; Stübner et al. 2016). The high abundance of meroplankton in Kongsfjorden might reflect a large adult biomass that inhabits the benthos in this region (Paar et al. 2015). Another important factor influencing the distribution of benthic invertebrate larvae may be their advective transport (Mileikovsky 1968). If this is the case, one would expect that populations of adults living in the shelf and along the coast outside Kongsfjorden might produce larvae that would be transported by advection into Kongsfjorden. Unfortunately, we do not currently have information about the distribution of meroplankton outside the fjords, making it impossible to verify this possibility. The significant correlation between meroplankton density and temperature (Table 7) suggests an important effect of temperature on the biological dynamics of larval populations (Lindley and Kirby 2007; Dvoretsky and Dvoretsky 2015) and confirms that hydrography might be important for the occurrence and distribution of invertebrate larvae in 
(a) Zooplankton community structure - taxonomic affiliations

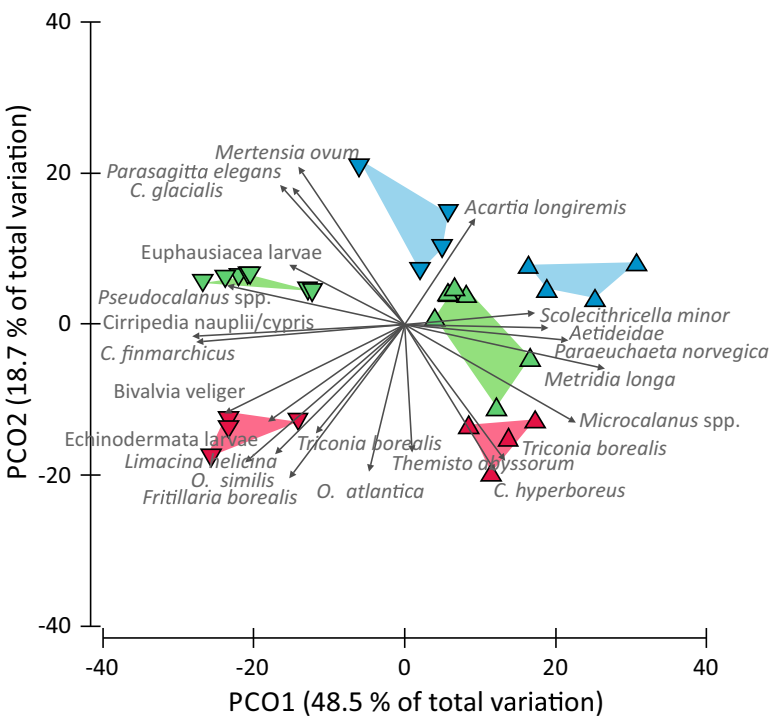

(b) Holoplankton community structure - zoogeographical affiliations

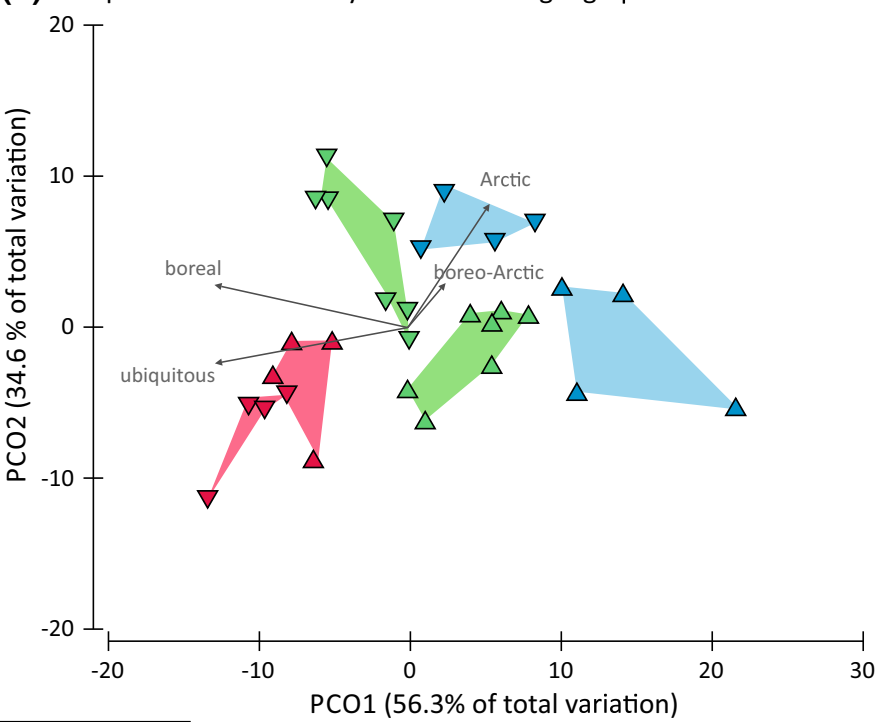

\begin{tabular}{|ll|}
\hline Layer: & Fjord: \\
$\nabla$ Upper & $\square$ Hornsund \\
$\triangle$ Lower & $\square$ Isfjorden \\
& $\square$ Kongsfjorden \\
\hline
\end{tabular}

Fig. 5 Ordination plots (PCO, Bray-Curtis similarity) based on the square-root-transformed zooplankton community structures according to taxonomic (a) and zoogeographical (b) compositions. Lines link points representing the same fjords and water layers. Vectors indicate the variables best correlated with the ordination coordinates and vector lengths correspond with the correlation values. For the clarity of the graph (a), only correlation values of $r>0.5$ are presented
Table 6 Results of the DistLM analysis for fitting environmental variables to the zooplankton community structure (regarding the taxonomic and zoogeographical composition)

Table 7 Spearman's rankorder correlation coefficients $(R)$ between zooplankton abundance (total and for different ecological groups distinguished based on the lifetime spent as plankton and on taxonomic and zoogeographical affiliations) in the upper and lower layers and the hydrographic data

\begin{tabular}{|c|c|c|c|c|c|c|}
\hline \multicolumn{3}{|l|}{ Marginal tests } & \multicolumn{4}{|c|}{ Sequential tests } \\
\hline Variable & Pseudo- $F$ & $R^{2}$ & Variable & Pseudo- $F$ & $R^{2}$ & Cum $R^{2}$ \\
\hline \multicolumn{7}{|c|}{ Zooplankton community taxonomic structure } \\
\hline Temperature & $9.2 * *$ & 0.25 & Temperature & 9.2 & $0.25 * *$ & 0.25 \\
\hline Salinity & $5.9 * *$ & 0.17 & Salinity & 6.7 & $0.15^{* *}$ & 0.40 \\
\hline \multicolumn{7}{|c|}{ Holoplankton zoogeographical affiliation } \\
\hline Temperature & $11.8 * *$ & 0.30 & Temperature & 11.8 & $0.30 * *$ & 0.30 \\
\hline Salinity & $3.0^{*}$ & 0.10 & Salinity & 5.8 & $0.12 * *$ & 0.42 \\
\hline
\end{tabular}

Analyses are based on square-root-transformed data of the species relative abundances in the samples Significant effects: $* p<0.05 ; * * p<0.001$

\begin{tabular}{|c|c|c|c|c|}
\hline & \multicolumn{2}{|l|}{ Upper Layer } & \multicolumn{2}{|l|}{ Lower layer } \\
\hline & Temperature & Salinity & Temperature & Salinity \\
\hline Total zooplankton & $0.911 * *$ & $0.604 *$ & 0.404 & 0.261 \\
\hline Meroplankton & $0.907 * *$ & $0.714^{*}$ & -0.175 & -0.100 \\
\hline Holoplankton & $0.754 *$ & $0.561^{*}$ & 0.404 & 0.268 \\
\hline Arctic holoplankton & 0.125 & -0.421 & 0.061 & -0.097 \\
\hline Boreo-Arctic holoplankton & 0.066 & 0.161 & $-0.532^{*}$ & $-0.611^{*}$ \\
\hline Boreal holoplankton & $0.752 *$ & $0.554^{*}$ & 0.354 & $0.596^{*}$ \\
\hline Ubiquitous holoplankton & $0.664 *$ & $0.679 *$ & $0.672 *$ & $0.602 *$ \\
\hline
\end{tabular}

Significant effects: $* p<0.05 ; * * p<0.001$ 
the plankton community (Schlüter and Rachor 2001; Fetzer and Arntz 2008). Another important factor accounting for the high meroplankton numbers in Isfjorden and particularly in Kongsfjorden may be the strong influence of AW during winter that prevents the fjords from freezing (Nilsen et al. 2008). The low number of meroplankton in Hornsund was within the previously reported range (Piwosz et al. 2009; Trudnowska et al. 2014) and may indicate that the seasonal succession of the plankton community is delayed in the more Arctic fjord, as was observed between Ripfjorden and Kongsfjorden (Rokkan Iversen and Seuthe 2011; Hodal et al. 2012; Weydmann et al. 2013). The sea ice cover may slightly delay the phytoplankton bloom and the subsequent meroplankton succession in Hornsund, due to the later development and progression of benthos. Therefore, some of the differences in meroplankton abundance and distribution between fjords may be due to the different successional stages, although this cannot be properly assessed based on this study. Studies of seasonal plankton communities have shown that the peak of the Cirripedia larvae in Arctic Ripfjorden occurred during the phytoplankton bloom in July (Weydmann et al. 2013), which was later than those observed during spring in the more sub-Arctic Adventfjorden (Stübner et al. 2016). The observed differences were related not only to the period of the bloom peak but also to meroplankton biomass (one order of magnitude lower in Ripfjorden). With the increasing warming trend in the Arctic, we can expect changes in the timing and magnitude of the meroplankton abundance because of anticipated expansion of boreal benthic species into the Arctic areas (Berge et al. 2006) and their subsequent establishment of reproducing populations.

The holoplankton assemblages found in the present study were composed of organisms having boreal, boreoArctic, Arctic and ubiquitous zoogeographical affiliations, indicating the open nature of the studied fjord systems. Consistent with previous observations (Kwasniewski et al. 2003; Piwosz et al. 2009; Walkusz et al. 2009; Weydmann et al. 2013; Trudnowska et al. 2014), our study showed that the holoplankton community in the west Spitsbergen fjords was characterised by the high dominance of a small number of species. Four species/genera (C. glacialis, C. finmarchicus, Pseudocalanus spp., including above all $P$. minutus and $P$. acuspes, and $O$. similis), each of them from different zoogeographical regions constituted $>60 \%$ of the total holoplankton abundance in the studied area.

Calanus glacialis and C. finmarchicus are key components of high-latitude ecosystems (Unstad and Tande 1991; Head et al. 2003). Although their centres of distribution are different (Arctic and boreal, respectively; Conover 1988; Unstad and Tande 1991), they largely overlap in transitional zones between sub-Arctic and Arctic water masses (Jaschnov 1972; Head et al. 2003; Parent et al. 2011, 2012), such as the WSS. Despite the differences in hydrography, the abundance of Arctic holoplankton was comparable along the WSS and was in the same range as that reported in previous studies (Scott et al. 2002; Kwasniewski et al. 2003, 2010; Basedow et al. 2004; Hop et al. 2006; Weydmann and Kwasniewski. 2008; Piwosz et al. 2009; Vogedes et al. 2014). Thus, it seems that in 2007, the west Spitsbergen fjords still contained reservoirs of cold ArW in the bottom layers or in basins separated by sills, offering refugia for Arctic species (Arnkværn et al. 2005; Weydmann and Kwasniewski 2008) and making it possible for Arctic C. glacialis to survive in the face of climate warming. For example, the abundances of $C$. glacialis copepodid stage $\mathrm{V}$, which is a preferred food item for Little Auk (Alle alle), were comparable in 2007 not only between Hornsund and Kongsfjorden but also in Magdalenefjorden, which is influenced by AW masses (our study, Kwasniewski et al. 2010; Vogedes et al. 2014) and were similar to those found earlier by Steen et al. (2007) and later by Jakubas et al. (2011) and Trudnowska et al. (2012). A time series study on the WSS near Hornsund (Kwasniewski et al. 2012) indicated that after 2001, the total abundance of the Arctic zooplankton community and the abundance of $C$. glacialis showed only minor fluctuations. On the other hand, with the continued warming trend in the Arctic, we can expect that climate-induced changes in tidewater glaciers will likely lead to the disappearance of reservoirs of cold ArW in the inner basins and, consequently, to substantial distributional shifts and abundance reductions for many arctic species (Lydersen et al. 2014).

Our study indicate that increasing amounts of warm Atlantic origin waters in the fjords might result in increased abundances of boreal species, mainly $C$. finmarchicus. The abundance of this boreal species increased from Hornsund to Isfjorden and further to Kongsfjorden in parallel with the observed increase in the amount of AW or TAW. According to Gabrielsen et al. (2012), using body (prosome) length for species identification may cause misidentification of $C$. finmarchicus specimens at the expense of $C$. glacialis due to phenotypic plasticity and the negative relationship between body size and temperature. We consider that this may be a problem but we believe it to be more consequential in studies of isolated populations, such as that in Billefjorden (Arnkværn et al. 2005). The populations of Calanus in Isfjorden, especially Kongsfjorden, are most likely supported by individuals advected into the fjords from the SC and the WSC. Thus, applying the size distribution method for species identification, based on earlier measurements from convergence areas, is expected to provide reliable results. Additionally, because similar methods have been in use for a number of studies (Kwasniewski et al. 2003; Hop et al. 2006; Vogedes et al. 2014), adhering to this approach allows for obtaining 
comparable results. Walkusz et al. (2009) and Kwasniewski et al. (2013) observed higher abundances of $C$. finmarchicus in Kongsfjorden during summer, after the disappearance of the hydrographic front that is usually present during winter and that limits the water mass exchange between fjords and open sea waters, particularly during cold years. During summer 2007, the density fronts near Kongsfjorden and Isfjorden were substantially reduced because of advection of Atlantic Water during winter, with resulting loss of sea ice (Cottier et al. 2007, 2010; Nilsen et al. 2008). This likely caused increased advection of warm-water boreal zooplankton species into the fjords. Increasing numbers of boreal copepods, as well as the associated shifts in the composition of the copepod assemblage, have been observed in the WSC from 2001 to 2009 (Weydmann et al. 2014). These observations suggest biogeographical shifts in zooplankton distribution similar to those observed in the North Atlantic and European shelf seas beginning in the mid-1980s (Beaugrand et al. 2002), which were manifested as northward extensions of warm-water species. The thermal biogeographical analysis used by Stuart-Smith et al. (2015) showed that large changes in the composition of species are caused by their thermal limits, although many marine invertebrates have a wide tolerance to changing temperatures $\left(0-15{ }^{\circ} \mathrm{C}\right.$ for cold water species). The distribution of Calanus in the fjords of west Spitsbergen in our study supports previous results showing that this is the region of 'overlapping zoogeographical borders' of Arctic and boreal species.

Most studies of zooplankton in the Arctic and subarctic seas focused on large-bodied copepods, although recent observations have shown the importance of small-bodied species, particularly in coastal waters and fjords systems (Auel and Hagen 2002; Lischka and Hagen 2005; Arendt et al. 2010; Svensen et al. 2011). Oithona similis is an abundant and ubiquitous species (Gallienne and Robins 2001) that is adapted to a wide range of habitats (Fransz and Gonzalez 1995). This cyclopoid copepod was also the most numerous holoplankton organism in our study as well as in other studies of the Spitsbergen fjords (Table 4; Hop et al. 2002a, b; Lischka and Hagen 2005; Walkusz et al. 2009). The high abundances of $O$. similis in the west Spitsbergen fjords, particularly in Kongsfjorden, identified using the imperfect medium mesh size sampling tool, may be associated with the observed increase in the amount of AW in this fjord. Low abundances of $O$. similis $(<1000$ ind $\mathrm{m}^{-3}$ ) in Hornsund were noted in the years before our studies (Kwasniewski 1990; Lischka and Hagen 2005; Piwosz et al. 2009) and were also confirmed in 2012 (Trudnowska et al. 2014). Kongsfjorden has been suggested as a favourable ecosystem for $O$. similis, due to the co-occurrence of different water masses, together with strong environmental gradients and a local circulation pattern (Walkusz et al. 2009). The role of $O$. similis may become even more important (Hansen et al. 2003) because cyclopoid species are generally able to survive a wide range of changes in environmental factors (Ward and Hirst 2007). Thus, $O$. similis may actually benefit from increasing temperature in the Arctic (Narcy et al. 2009), and there are observations showing that the abundance of $O$. similis seems to have gradually increased in Kongsfjorden since 2006 (http://mosj.npolar.no/no/). Another factor that may influence the observed discrepancy in the abundance of $O$. similis between the fjords could be the difference in the seasonal development of the ecosystems. The peak abundance of $O$. similis typically occurs in August/September (Lischka and Hagen 2005), towards the end of the growth season, which may occur earlier in warmer Kongsfjorden than in cold Hornsund. Although it is still a matter of debate whether the consequences of the changes in the abundance of small-sized zooplankton species to the ecosystem will be more important than changes in largebodied zooplankton, some studies postulate that changes in the community size structure are more important than changes in the zooplankton biomass (Richardson and Schoeman 2004; Lane et al. 2008).

Water temperature and salinity had measurable effects on the zooplankton community in the study area. This was based on our examination of the influence of hydrographic environmental factors (water temperature and salinity) on selected aspects of the zooplankton community structure (including lifespan as plankton and taxonomic and zoogeographical affiliations) using multivariate statistical analysis, along with an analysis of the correlations between hydrographic factors and selected, univariate zooplankton characteristics. Our results agree with those of other studies and show that the environmental conditions of the waters lead to the spatial differentiation of zooplankton communities (Daase et al. 2007; Blachowiak-Samolyk et al. 2008; Kwasniewski et al. 2010; Estrada et al. 2012; Dalpadado et al. 2015; Trudnowska et al. 2015). The authors concluded that the abundance of both Atlantic-associated $(C$. finmarchicus) and ubiquitous species, such as $O$. similis, increased with increasing temperature, as a consequence of faster development and shorter time needed to complete their life cycles (Huntley and Lopez 1992; Møller et al. 2012) or by influencing the relationships among species (Ji et al. 2012). Although the results presented here concur with earlier research, this was the first attempt to assess the importance of hydrography on the zooplankton community structure not only in terms of the taxonomic composition but also in terms of the zoogeographical affiliation and the proportions of holoplankton and meroplankton.

This study and previous observations in these regions indicate that the structure and function of the pelagic 
ecosystem of the West Spitsbergen Shelf and adjacent fjords will be affected by the increasing influence of AW (Piechura and Walczowski 2009). Our study was performed during the same year at three west Spitsbergen fjords reflecting a variety of oceanographic conditions from Arctic to Atlantic environments. Hornsund, the fjord with the smallest amount of Atlantic-type water contained a zooplankton community composed of boreo-Arctic and Arctic species, with relatively low abundances of the ubiquitous $(O$. similis) and boreal (C. finmarchicus) species. The other end of the studied environmental gradient span is represented by the situation observed in Kongsfjorden, the fjord with a substantial amount of AW, with higher water temperature and salinity. The zooplankton community in this fjord was characterised by a significantly higher total abundance, resulting from higher abundances of ubiquitous and boreal, warm-water species, as well as significantly higher meroplankton numbers. Thus, if the ongoing climate warming and the associated changes in the marine environment continue or intensify, we can expect increased advection of AW into fjords, even those regarded as Arctic fjords (as occurred in 2014 in Hornsund). Consequently, we anticipate higher zooplankton abundances and modifications of the zooplankton community structure, resulting from increased occurrence of boreal and ubiquitous species and increased contributions of meroplankton. In addition, because meroplankton and the boreal and ubiquitous holoplankton species are usually smaller, the size structure of the zooplankton community will also change. This will influence the function of the community (Richardson and Schoeman 2004; Lane et al. 2008), with effects radiating onto other ecosystem components and functions (Stempniewicz et al. 2007). The present occurrence of Arctic species in the Atlantic-influenced fjords of west Spitsbergen suggests that the marine ecosystem in this part of the Arctic is still in the stage of 'rickety balance' and 'regime overlapping' rather than complete 'regime shift'. Acknowledgments We thank the crews of the research vessels
'Oceania' and 'Helmer Hanssen' for their assistance during sampling.
This study is part of the synoptic ALBERT (Arctic Life: Bridging
Ecosystem function using Remote Technologies, IPY/29/2007)
campaign and part of the MariClim project (Marine ecosystem con-
sequences of climate-induced changes in water masses off west
Spitsbergen, 165112/S30) funded by the Research Council of Nor-
way. This paper was completed with the financial support of the
Polish Ministry of Science, Grants $0377 / \mathrm{B} / \mathrm{P} 01 / 2011 / 40,5 / \mathrm{MariClim} /$
$2006 / 0$ and 1177/IPY/2007/01. The first author and JMW were
financially supported through the Face2Face $(2012 / 05 / \mathrm{B} / \mathrm{ST} 10)$ and
GAME (2012/04/A/NZ8/00661) projects funded by the Polish
National Science Centre. IG received support from the Polish
National Science Centre, MIXAR grant agreement No. 2012/05/N/
ST10/03643. AP's doctoral project and the language corrections
throughout the manuscript were funded by the Leading National
Research Centre (KNOW) as received by the Centre for Polar Studies for the period 2014-2018. Finally, we thank the anonymous reviewers for their suggestions to improve the manuscript.

Open Access This article is distributed under the terms of the Creative Commons Attribution 4.0 International License (http://crea tivecommons.org/licenses/by/4.0/), which permits unrestricted use, distribution, and reproduction in any medium, provided you give appropriate credit to the original author(s) and the source, provide a link to the Creative Commons license, and indicate if changes were made.

\section{References}

Aksnes DL, Blindheim J (1996) Circulation patterns in the North Atlantic and possible impact on population dynamics of Calanus finmarchicus. Ophelia 44:7-28

Anderson MJ (2001) Permutation tests for univariate or multivariate analysis of variance and regression. Can J Fish Aquat Sci 58:626-639

Anderson M, Gorley RN, Clarke RK (2008) Permanova+ for primer: guide to software and statistical methods. PRIMER-E Ltd, Plymouth

Arendt KE, Nielsen TG, Rysgaard S, Tönnesson K (2010) Differences in plankton community structure along the Godthåbsfjord, from the Greenland Ice Sheet to offshore waters. Mar Ecol Prog Ser 401:49-62

Arnkværn G, Daase M, Eiane K (2005) Dynamics of coexisting Calanus finmarchicus, Calanus glacialis and Calanus hyperboreus populations in a high-Arctic fjord. Polar Biol 28:528-538

Auel H, Hagen W (2002) Mesozooplankton community structure, abundance and biomass in the central Arctic Ocean. Mar Biol 140:1013-1021

Basedow SL, Eiane K, Tverberg V, Spindler M (2004) Advection of zooplankton in an Arctic fjord (Kongsfjorden, Svalbard). Estuar Coast Shelf Sci 60:113-124

Beaugrand G, Reid PC, Ibanez F, Lindley JA, Edwards M (2002) Reorganization of North Atlantic marine copepod biodiversity and climate. Science 296:1692-1694

Berge J, Johnsen G, Nilsen F, Gulliksen B, Slagstad D, Pampanin DM (2006) The Mytilus edulis population in Svalbard: how and why. Mar Ecol Prog Ser 309:305-306

Berge J, Cottier F, Varpe Ø, Renaud PE, Falk-Petersen S, Kwasniewski S, Søreide JE, Johnsen G, Aubert A, Bjærke O, Hovinen J, Jung-Madsen S, Tveit M, Majaneva S (2014) Arctic complexity: a case study on diel vertical migration of zooplankton. J Plankton Res 36:1279-1297

Beszczynska-Möller A, Fahrbach E, Schauer U, Hansen E (2012) Variability in Atlantic water temperature and transport at the entrance to the Arctic Ocean, 1997-2010. ICES J Mar Sci 69:852-863

Beuchel F, Lønne OJ (2002) Population dynamics of the sympagic amphipods Gammarus wilkitzkii and Apherusa glacialis in sea ice north of Svalbard. Polar Biol 25:241-250

Blachowiak-Samolyk K, Søreide JE, Kwasniewski S, Sundfjord A, Hop H, Falk-Petersen S, Hegseth EN (2008) Hydrodynamic control of mesozooplankton abundance and biomass in northern Svalbard waters (79-81 N). Deep Sea Res II 55:2210-2224

Buchholz F, Buchholz C, Weslawski JM (2010) Ten years after: krill as indicator of changes in the macro-zooplankton communities of two Arctic fjords. Polar Biol 33:101-113

Burrows MT, Schoeman DS, Buckley LB, Moore P, Poloczanska ES, Brander KM, Brown C, Bruno JF, Duarte CM, Halpern BS, Holding J, Kappel CV, Kiessling W, O'Connor MI, Pandolfi JM, Parmesan C, Schwing FB, Sydeman WJ, Richardson AJ (2011) 
The pace of shifting climate in marine and terrestrial ecosystems. Science 334:652-655

Burrows MT, Schoeman DS, Richardson AJ, Molinos JG, Hoffmann A, Buckley LB, Moore PJ, Brown CJ, Bruno FJ, Duarte CM, Halpern BS, Hoegh-Guldberg O, Kappel CV, Kiessling W, O'Connor MI, Pandolfi JM, Parmesan C, Sydeman WJ, Ferrier S, Williams KJ, Poloczanska ES (2014) Geographical limits to species-range shifts are suggested by climate velocity. Nature 507:492-495

Busch K, Bauerfeind E, Nöthig EM (2015) Pteropod sedimentation patterns in different water depths observed with moored sediment traps over a 4-year period at the LTER station Hausgarten in eastern Fram Strait. Polar Biol 38:845-859

Carroll ML, Ambrose WG Jr, Levin BS, Henkes GA, Hop H, Renaud PE (2011) Pan-Svalbard growth rate variability and environmental regulation in the Arctic bivalve Serripes groenlandicus. J Mar Syst 88:239-251

Clarke KR, Gorley RN (2001) Primer. Primer-e Ltd., Plymouth

Clarke KR, Warwick RM (2001) Change in marine communities: an approach to statistical analysis and interpretation, 2nd edn. PRIMER-E, Plymouth

Conover RJ (1988) Comparative life histories in the genera Calanus and Neocalanus in high latitudes of the Northern Hemisphere. Hydrobiologia 167:127-142

Corkett I, McLaren A (1979) The Biology of Pseudocalanus. Adv Mar Biol 15:1-231

Cottier FR, Venables EJ (2007) On the double-diffusive and cabbeling environment of the Arctic Front, West Spitsbergen. Polar Res 26:152-159

Cottier F, Tverberg V, Inall M, Svendsen H, Nilsen F, Griffiths C (2005) Water mass modification in an Arctic fjord through crossshelf exchange: the seasonal hydrography of Kongsfjorden, Svalbard. J Geophys Res 110:C12005

Cottier FR, Nilsen F, Inall ME, Gerland S, Tverberg V, Svendsen H (2007) Wintertime warming of an Arctic shelf in response to large-scale atmospheric circulation. Geophys Res Lett 34:L10607

Cottier FR, Nilsen F, Skogseth R, Tverberg V, Skarðhamar J, Svendsen H (2010) Arctic fjords: a review of the oceanographic environment and dominant physical processes. Geol Soc Spec Publ 344:35-50

Daase M, Vik JO, Bagoien E, Stenseth NC, Eiane K (2007) The influence of advection on Calanus near Svalbard: statistical relations between salinity, temperature and copepod abundance. J Plankton Res 29:903-911

Dalpadado P, Skjoldal HR (1996) Abundance, maturity and growth of the krill species Thysanoessa inermis and $T$. longicaudata the Barents Sea. Mar Ecol Prog Ser 144:175-183

Dalpadado P, Borkner N, Bogstad B, Mehl S (2001) Distribution of Themisto (Amphipoda) spp. in the Barents Sea and predatorprey interactions. ICES J Mar Sci 58:876-895

Dalpadado P, Hop H, Rønning J, Pavlov V, Sperfeld E, Buchholz F, Rey A, Wold A (2015) Distribution and abundance of euphausiids and pelagic amphipods in Kongsfjorden, Isfjorden and Rijpfjorden (Svalbard) and changes in their relative importance as key prey in a warming marine ecosystem. Polar Biol. doi:10. 1007/s00300-015-1874-x

Dvoretsky VG, Dvoretsky AG (2015) Regional differences of mesozooplankton in the Kara Sea. Cont Shelf Res 105:26-41

Eilertsen HC, Taasen JP, WesIawski JM (1989) Phytoplankton studies in the fjords of West Spitzbergen: physical environment and production in spring and summer. $\mathbf{J}$ Plankton Res 11:1245-1260

Estrada R, Harvey M, Gosselin M, Starr M, Galbraith PS, Straneo F (2012) Late-summer zooplankton community structure, abundance, and distribution in the Hudson Bay system (Canada) and their relationships with environmental conditions, 2003-2006. Progr Oceanogr 101:121-145

Fetzer I, Arntz WE (2008) Reproductive strategies of benthic invertebrates in the Kara Sea (Russian Arctic): adaptation of reproduction modes to cold water. Mar Ecol Prog Ser 356:189-202

Fransz HG, Gonzalez SR (1995) The production of Oithona similis (Copepoda: Cyclopoida) in the Southern Ocean. ICES J Mar Sci 52:549-555

Gabrielsen TM, Merkel B, Søreide JE, Johansson-Karlsson E, Bailey A, Vogedes D, Nygård H, Varpe $\varnothing$, Berge J (2012) Potential misidentifications of two climate indicator species of the marine arctic ecosystem: Calanus glacialis and C. finmarchicus. Polar Biol 35:1621-1628

Gallienne CP, Robins DB (2001) Is Oithona the most important copepod in the world's oceans? J Plankton Res 23:1421-1432

Graeve M, Lundberg M, Böer M, Kattner G, Hop H, Falk-Petersen S (2008) The fate of dietary lipids in the Arctic ctenophore Mertensia ovum (Fabricius 1780). Mar Biol 153:643-651

Hallanger IG, Ruus A, Warner NA, Herzke D, Evenset A, Schøyen M, Gabrielsen GW, Borgå K (2011) Differences between Arctic and Atlantic fjord systems on bioaccumulation of persistent organic pollutants in zooplankton from Svalbard. Sci Total Environ 409:2783-2795

Hansen AS, Nielsen TG, Levinsen H, Madsen SD, Thingstad TF, Hansen BW (2003) Impact of changing ice cover on pelagic productivity and food web structure in Disko Bay, West Greenland: a dynamic model approach. Deep Sea Res I 50:171-187

Head EJH, Harris LR, Yashayaev I (2003) Distributions of Calanus spp. and other mesozooplankton in the Labrador Sea in relation to hydrography in spring and summer (1995-2000). Progr Oceanogr 59:1-30

Heath MR, Backhaus JO, Richardson K, McKenzie E, Slagstad D, Beare D, Dunn J, Fraser JG, Gallego A, Hainbucher D, Hay S, Jónasdóttir S, Madden H, Mardaljevic J, Schacht A (1999) Climate fluctuations and the spring invasion of the North Sea by Calanus finmarchicus. Fish Oceanogr 8:163-176

Hirche HJ, Kosobokova K (2007) Distribution of Calanus finmarchicus in the northern North Atlantic and Arctic Ocean-expatriation and potential colonization. Deep Sea Res II 54:2729-2747

Hodal H, Falk-Petersen S, Hop H, Kristiansen S, Reigstad M (2012) Spring bloom dynamics in Kongsfjorden, Svalbard: nutrients, phytoplankton, protozoans and primary production. Polar Biol 35(2):191-203

Hop H, Gjøsæter H (2013) Polar cod (Boreogadus saida) and capelin (Mallotus villosus) as key species in marine food webs of the Arctic and the Barents Sea. Mar Biol Res 9:878-894

Hop H, Borgå K, Gabrielsen GW, Kleivane L, Skaare JU (2002a) Food web magnification of persistent organic pollutants in poikilotherms and homeotherms from the Barents Sea food web. Environ Sci Technol 36:2589-2597

Hop H, Pearson T, Hegseth EN, Kovacs KM, Wiencke C, Kwasniewski S, Eiane K, Mehlum F, Gulliksen B, WlodarskaKowalczuk M, Lydersen C, Weslawski JM, Cochrane S, Gabrielsen GW, Leakey RJG, Lønne OJ, Zajaczkowski M, Falk-Petersen S, Kendall M, Wängberg S-Ä, Bischof $\mathrm{K}$, Voronkov AY, Kovaltchuk NA, Wiktor J, Poltermann M, di Prisco G, Papucci C, Gerland S (2002b) The marine ecosystem of Kongsfjorden, Svalbard. Polar Res 21:167-208

Hop H, Falk-Petersen S, Svendsen H, Kwasniewski S, Pavlov V, Pavlova O, Søreide JE (2006) Physical and biological characteristics of the pelagic system across Fram Strait to Kongsfjorden. Prog Oceanogr 71:182-231

Hovinen JEH, Welcker J, Rabindranath A, Brown ZW, Hop H, Berge J, Steen H (2014) At-sea distribution of foraging little auks 
relative to physical factors and potential food supply. Mar Ecol Prog Ser 503:263-277

Huntley ME, Lopez MD (1992) Temperature-dependent production of marine copepods: a global synthesis. Am Nat 140:201-242

Inall ME, Nilsen F, Cottier FR, Daae R (2015) Shelf/fjord exchange driven by coastal-trapped waves in the Arctic. J Geophys Res Oceans 120:8283-8303. doi:10.1002/2015JC011277

Ito H, Kudoh S (1997) Characteristics of water in Kongsfjorden, Svalbard. Proc NIPR Symp Polar Meteorol Glaciol 11:211-232

Jakubas D, Gluchowska M, Wojczulanis-Jakubas K, Karnovsky NJ, Keslinka L, Kidawa D, Walkusz W, Boehnke R, Cisek M, Kwasniewski S, Stempniewicz L (2011) Foraging effort does not influence body condition and stress level in little auks. Mar Ecol Prog Ser 432:277-290

Jaschnov WA (1972) On the systematic status of Calanus glacialis, Calanus finmarchicus and Calanus helgolandicus. Crustaceana 22:279-284

Ji R, Ashjian CJ, Campbell RG, Chen C, Gao G, Davis CS, Cowles GW, Beardsley RC (2012) Life history and biogeography of Calanus copepods in the Arctic Ocean: an individual-based modeling study. Prog Oceanogr 96:40-56

Kosobokova K, Hirche HJ, Scherzinger T (2002) Feeding ecology of Spinocalanus antarcticus, a mesopelagic copepod with a looped gut. Mar Biol 141:503-511

Kosobokova KN, Hopcroft RR, Hirche HJ (2011) Patterns of zooplankton diversity through the depths of the Arctic's central basins. Mar Biodiv 41:29-50

Koszteyn J, Kwasniewski S (1989) Comparison of fjord and shelf mesozooplankton communities of the southern Spitsbergen region. Rapp Pv Rèun Cons Int l'Explor Mer 188:164-169

Koszteyn J, Timofeev S, Weslawski JM, Malinga B (1995) Size structure of Themisto abyssorum Boeck and Themisto libellula (Mandt) populations in European Arctic seas. Polar Biol 15:85-92

Kraft A, Nöthig EM, Bauerfeind E, Wildish DJ, Pohle GW, Bathmann U, Beszczynska-Möller A, Klages M (2013) First evidence of reproductive success in a southern invader indicates possible community shifts among Arctic zooplankton. Mar Ecol Prog Ser 493:291-296

Kuklinski P, Berge J, McFadden L, Dmoch K, Zajaczkowski M, Nygård H, Piwosz K, Tatarek A (2013) Seasonality of occurrence and recruitment of Arctic marine benthic invertebrate larvae in relation to environmental variables. Polar Biol 36:549-560

Kwasniewski S (1990) A note on zooplankton of the Hornsund Fjord and its seasonal changes. Oceanografia 12:7-27

Kwasniewski S, Hop H, Falk-Petersen S, Pedersen G (2003) Distribution of Calanus species in Kongsfjorden, a glacial fjord in Svalbard. J Plankton Res 25:1-20

Kwasniewski S, Gluchowska M, Jakubas D, Wojczulanis-Jakubas K, Walkusz W, Karnovsky N, Blachowiak-Samolyk K, Cisek M, Stempniewicz L (2010) The impact of different hydrographic conditions and zooplankton communities on provisioning Little Auks along the West coast of Spitsbergen. Prog Oceanogr 87:72-82

Kwasniewski S, Gluchowska M, Walkusz W, Karnovsky NJ, Jakubas D, Wojczulanis-Jakubas K, Wojczulanis-Jakubas K, Harding AMA, Goszczko I, Cisek M, Beszczynska-Møller A, Walczowski W, Weslawski JM, Stempniewicz L (2012) Interannual changes in zooplankton on the West Spitsbergen Shelf in relation to hydrography and their consequences for the diet of planktivorous seabirds. ICES J Mar Sci 69:890-901

Kwasniewski S, Walkusz W, Cottier FR, Leu E (2013) Mesozooplankton dynamics in relation to food availability during spring and early summer in a high latitude glaciated fjord (Kongsfjorden), with focus on Calanus. J Mar Syst 111:83-96

Lane PV, Llinás L, Smith SL, Pilz D (2008) Zooplankton distribution in the western Arctic during summer 2002: hydrographic habitats and implications for food chain dynamics. J Mar Syst 70:97-133
Lind S, Ingvaldsen RB (2012) Variability and impacts of Atlantic Water entering the Barents Sea from the north. Deep Sea Res I 62:70-88. doi:10.1016/j.dsr.2011.12.007

Lindley JA, Kirby RR (2007) Long-term changes in the meroplankton of the North Sea. ICES CM 2007(A:16):1-10

Lischka S, Hagen W (2005) Life histories of the copepods Pseudocalanus minutus, P. acuspes (Calanoida) and Oithona similis (Cyclopoida) in the Arctic Kongsfjorden (Svalbard). Polar Biol 28:910-921

Lydersen C, Assmy P, Falk-Petersen S, Kohler J, Kovacs KM, Reigstad M, Steen H, Strøm H, Sundfjord A, Varpe $\varnothing$, Walczowski W, Weslawski JM, Zajaczkowski M (2014) The importance of tidewater glaciers for marine mammals and seabirds in Svalbard, Norway. J Mar Syst 129:452-471

Mileikovsky SA (1968) Distribution of pelagic larvae of bottom invertebrates of the Norwegian and Barents Seas. Mar Biol $1: 161-167$

Møller EF, Maar M, Jónasdóttir SH, Nielsen TG, Tönnesson K (2012) The effect of changes in temperature and food on the development of Calanus finmarchicus and Calanus helgolandicus populations. Limnol Oceanogr 57:211-220

Muckenhuber S, Nilsen F, Korosov A, Sandven S (2015) Sea ice cover in Isfjorden and Hornsund 2000-2014 from remote sensing data. Cryosphere 10:149-158

Nahrgang J, Varpe $\varnothing$, Korshunova E, Murzina S, Hallanger IG, Vieweg I, Berge J (2014) Gender specific reproductive strategies of an Arctic key species (Boreogadus saida) and implications of climate change. PLoS One 9:e98452

Narcy F, Gasparini S, Falk-Petersen S, Mayzaud P (2009) Seasonal and individual variability of lipid reserves in Oithona similis (Cyclopoida) in an Arctic fjord. Polar Biol 32:233-242

Nilsen F, Cottier F, Skogseth R, Mattsson S (2008) Fjord-shelf exchanges controlled by ice and brine production: the interannual variation of Atlantic Water in Isfjorden, Svalbard. Cont Shelf Res 28:1838-1853

Nilsen F, Skogseth R, Vaardal-Lunde J, Inall M (2016) A simple shelf circulation model-intrusion of Atlantic Water on the West Spitsbergen Shelf. J Phys Oceanogr 46:1209-1230

Olli K, Wassmann P, Reigstad M, Ratkova TN, Arashkevich E, Pasternak A, Matrai PA, Knulst J, Tranvik L, Klais R, Jacobsen A (2007) The fate of production in the central Arctic Ocean-topdown regulation by zooplankton expatriates? Prog Oceanogr 72:84-113

Paar M, Voronkov A, Hop H, Brey T, Bartsch I, Schwanitz M, Wiencke C, Lebreton B, Asmus R, Asmus H (2015) Temporal shift in biomass and production of macrozoobenthos in the macroalgal belt at Hansneset, Kongsfjorden, after 15 years. Polar Biol. doi:10.1007/s00300-015-1760-6

Parent GJ, Plourde S, Turgeon J (2011) Overlapping size ranges of Calanus spp. off the Canadian Arctic and Atlantic Coasts: impact on species' abundances. J Plankton Res 33:1654-1665

Parent GJ, Plourde S, Turgeon J (2012) Natural hybridization between Calanus finmarchicus and C. glacialis (Copepoda) in the Arctic and Northwest Atlantic. Limnol Oceanogr 57:1057-1066

Park T (1994) Geographic distribution of the bathypelagic genus Paraeuchaeta (Copepoda, Calanoida). Hydrobiologia 292:317-332

Piechura J, Walczowski W (2009) Warming of the West Spitsbergen Current and sea ice north of Svalbard. Oceanologia 51:147-164

Piwosz K, Walkusz W, Hapter R, Wieczorek P, Hop H, Wiktor J (2009) Comparison of productivity and phytoplankton in a warm (Kongsfjorden) and a cold (Hornsund) Spitsbergen fjord in midsummer 2002. Polar Biol 32:549-559

Postel L, Fock H, Hagen W (2000) Biomass and abundance. In: Harris R, Wiebe P, Lens J, Skjoldal HR, Huntley M (eds) ICES zooplankton methodology manual. Academic Press, San Diego, pp 83-192 
Prominska A, Falck E, Walczowski W. Interannual variability in hydrography and water mass distribution in Hornsund, an Arctic fjord in Svalbard. Polar Research (in review)

Rabindranath A, Daase M, Falk-Petersen S, Wold A, Wallace MI, Berge J, Brierley AS (2011) Seasonal and diel vertical migration of zooplankton in the High Arctic during the autumn midnight sun of 2008. Mar Biodiv 41:365-382

Raymont JEG (1980) Plankton and productivity in the oceans. Phytoplankton, vol 1, 2nd edn. Pergamon Press Ltd., Oxford

Razouls C, Bovée F, Kouwenberg J, Desreumaux N (2005-2015) Diversity and geographic distribution of marine planktonic copepods. http://copepodes.obs-banyuls.fr/en/. Accessed $20 \mathrm{Sept}$ 2015

Renaud PE, Berge J, Varpe Ø, Lønne OJ, Nahrgang J, Ottesen C, Hallanger I (2012) Is the poleward expansion by Atlantic cod and haddock threatening native polar cod, Boreogadus saida? Polar Biol 35:401-412

Richardson AJ, Schoeman DS (2004) Climate impact on plankton ecosystems in the Northeast Atlantic. Science 305:1609-1612

Rokkan Iversen K, Seuthe L (2011) Seasonal microbial processes in a high-latitude fjord (Kongsfjorden, Svalbard): I. Heterotrophic bacteria, picoplankton and nanoflagellates. Polar Biol 34:731-749

Sakshaug E, Johnsen GH, Kovacs KM (2009) Ecosystem Barents Sea. Tapir Academic Press, Trondheim

Saloranta TM, Svendsen H (2001) Across the Arctic front west of Spitsbergen: high-resolution CTD sections from 1998-2000. Polar Res 20:177-184

Schellenberger T, Dunse T, Kaab A, Kohler J, Reijmer CH (2015) Surface speed and frontal ablation of Kronebreen and Kongsbreen, NW Svalbard, from SAR offset tracking. Chryosphere 9:2339-2355

Schlüter M, Rachor E (2001) Meroplankton distribution in the central Barents Sea in relation to local oceanographic patterns. Polar Biol 24:582-592

Scott CL, Kwasniewski S, Falk-Petersen S, Sargent JR (2002) Species differences, origins and functions of fatty alcohols and fatty acids in the wax esters and phospholipids of Calanus hyperboreus, C. glacialis and C. finmarchicus from Arctic waters. Mar Ecol Prog Ser 235:127-134

Steen H, Vogedes D, Broms F, Falk-Petersen S, Berge J (2007) Little auks (Alle alle) breeding in a High Arctic fjord system: bimodal foraging strategies as a response to poor food quality? Polar Res 26:118-125

Stempniewicz L, Blachowiak-Samołyk K, Weslawski JM (2007) Impact of climate change on zooplankton communities, seabird populations and Arctic terrestrial ecosystem-a scenario. Deep Sea Res II 54:2934-2945

Stuart-Smith RD, Edgar GJ, Barrett NS, Kininmonth SJ, Bates AE (2015) Thermal biases and vulnerability to warming in the world's marine fauna. Nature 528:88-92

Stübner EI, Søreide JE, Reigstad M, Marquardt M, BlachowiakSamolyk K (2016) Year-round meroplankton dynamics in highArctic Svalbard. J Plankton Res. doi:10.1093/plankt/fbv124

Svendsen H, Beszczynska-Møller A, Hagen JO, Lefauconnier B, Tverberg V, Gerland S, Ørbæk JB, Bischof K, Papucci C, Zajaczkowski M, Azzolini R, Bruland O, Wiencke C, Winther J-G, Dallmann W (2002) The physical environment of Kongsfjorden-Krossfjorden, an Arctic fjord system in Svalbard. Polar Res 21:133-166

Svensen C, Seuthe L, Vasilyeva Y, Pasternak A, Hansen E (2011) Zooplankton distribution across Fram Strait in autumn: Are small copepods and protozooplankton important? Progr Oceanogr 91:534-544

Swerpel S (1985) The Hornsund fiord: water masses. Pol Polar Res 6:475-496
Torgersen T, Huse G (2005) Variability in retention of Calanus finmarchicus in the Nordic Seas. ICES J Mar Sci 62:1301-1309

Trudnowska E, Szczucka J, Hoppe L, Boehnke R, Hop H, Blachowiak-Samolyk K (2012) Multidimensional zooplankton observations on the northern West Spitsbergen Shelf. J Mar Syst 98:18-25

Trudnowska E, Basedow SL, Blachowiak-Samolyk K (2014) Midsummer mesozooplankton biomass, its size distribution, and estimated production within a glacial Arctic fjord (Hornsund, Svalbard). J Mar Syst 137:55-66

Trudnowska E, Sagan S, Kwasniewski S, Darecki M, BlachowiakSamolyk K (2015) Fine-scale zooplankton vertical distribution in relation to hydrographic and optical characteristics of the surface waters on the Arctic shelf. J Plankton Res 37:120-133

Tverberg V, Nøst OA (2009) Eddy overturning across a shelf edge front: Kongsfjorden, west Spitsbergen. J Geophys Res 114:C04024

Unstad KH, Tande KS (1991) Depth distribution of Calanus finmarchicus and $C$. glacialis in relation to environmental conditions in the Barents Sea. Polar Res 10:409-420

Vogedes D, Eiane K, Båtnes AS, Berge J (2014) Variability in Calanus spp. abundance on fine-to mesoscales in an Arctic fjord: implications for little auk feeding. Mar Biol Res 10:437-448

Walczowski W, Piechura J, Goszczko I, Wieczorek P (2012) Changes in Atlantic water properties: an important factor in the European Arctic marine climate. ICES J Mar Sci 69:864-869

Walkusz W, Kwasniewski S, Falk-Petersen S, Hop H, Tverberg V, Wieczorek P, Weslawski JM (2009) Seasonal and spatial changes in the zooplankton community of Kongsfjorden, Svalbard. Polar Res 28:254-281

Wallace MI, Cottier FR, Berge J, Tarling GA, Griffiths C, Brierley AS (2010) Comparison of zooplankton vertical migration in an ice-free and a seasonally ice-covered Arctic fjord: an insight into the influence of sea ice cover on zooplankton behavior. Limnol Oceanogr 55(2):831-845

Ward P, Hirst AG (2007) Oithona similis in a high latitude ecosystem: abundance, distribution and temperature limitation of fecundity rates in a sac spawning copepod. Mar Biol 151:1099-1110

Wassmann P, Reigstad M, Haug T, Rudels B, Carroll ML, Hop H, Gabrielsen GW, Falk-Petersen S, Denisenko SG, Arashkevich E, Slagstad D, Pavlova O (2006) Food webs and carbon flux in the Barents Sea. Progr Oceanogr 71:232-287

Weslawski JM, Jankowski A, Kwasniewski S, Swerpel S, Ryg M (1991) Summer hydrology and zooplankton in two Svalbard fiords. Pol Polar Res 12:445-460

Weydmann A, Kwasniewski S (2008) Distribution of Calanus populations in a glaciated fjord in the Arctic (Hornsund, Spitsbergen) - the interplay between biological and physical factors. Polar Biol 31:1023-1035

Weydmann A, Søreide JE, Kwasniewski S, Leu E, Falk-Petersen S, Berge J (2013) Ice-related seasonality in zooplankton community composition in a high Arctic fjord. J Plankton Res 35:831-842

Weydmann A, Carstensen J, Goszczko I, Dmoch K, Olszewska A, Kwasniewski S (2014) Shift towards the dominance of boreal species in the Arctic: inter-annual and spatial zooplankton variability in the West Spitsbergen Current. Mar Ecol Prog Ser 501:41-52

Willis K, Cottier F, Kwasniewski S, Wold A, Falk-Petersen S (2006) The influence of advection on zooplankton community composition in an Arctic fjord (Kongsfjorden, Svalbard). J Mar Syst 61:39-54

Willis KJ, Cottier FR, Kwasniewski S (2008) Impact of warm water advection on the winter zooplankton community in an Arctic fjord. Polar Biol 31:475-481

WoRMS Editorial Board (2015) World Register of Marine Species. http://www.marinespecies.org. Accessed 20 Sept 2015 